\title{
Did democracy bring redistribution? Insights from the Spanish tax system, 1960-1990 ${ }^{1}$
}

\author{
Sara Torregrosa Hetland ${ }^{2}$
}

This document is the author's version (Accepted Manuscript) of:

Torregrosa-Hetland, S. (2015): "Did Democracy bring Redistribution? Insights from the Spanish tax system (1960-1990)", European Review of Economic History 19 (3), pp. 294315.

\begin{abstract}
The relationship between democracy, inequality and redistribution has inspired extensive research, but consensus is still elusive. In order to contribute to this discussion, the author analyses the Spanish case, where transition to democracy was accompanied by a comprehensive tax reform, aiming at increasing progressivity and revenue. But how effectively did it change the distribution of the tax burden? Was there a 'fiscal revolution'?

The results show that persistent regressivity (albeit decreasing) exacerbated income inequality, failing to attain convergence with more developed countries. The joint effect of the fiscal system, however, was slightly positive due to progressive social spending.
\end{abstract}

Keywords: tax system, progressivity, redistribution, income inequality, democratization.

JEL Codes: D31, N34, N44, H23

\footnotetext{
1 This paper is part of the $\mathrm{PhD}$ dissertation "Tax system and redistribution: the Spanish fiscal transition (1960-1990)", under the supervision of Alfonso Herranz-Loncán and Alejandro Esteller-Moré, to whom I am most grateful for their help. I also thank the comments by Mercè Costa, Sergio Espuelas, three anonymous referees and participants at seminars in Barcelona, Uppsala, Madrid, Girona, Mexico DF and Washington DC. I acknowledge financial support from the Spanish Ministry of Education's scholarship program Formación del Profesorado Universitario and the Research Project ECO201239169-C03-03. I also thank the kindness and professionality of personnel in the Public Finance Ministry Archive and the Institute for Fiscal Studies. I am in debt with Jorge Onrubia for kindly sharing his data on the Personal Income Tax.

${ }^{2}$ University of Barcelona, Department of Economic History and Institutions. 690 Avda. Diagonal, 08034 Barcelona. E-mail: storregrosa@ub.edu
} 


\section{Introduction}

"Do you think that, generally, taxes are fairly collected? That is, that the ones who own more pay more?",

During the last thirty years, approximately $80 \%$ of Spanish citizens would answer no to this question according to annual opinion polls (Alvira and García, 2005). Spaniards do not seem to believe that their tax system is progressive, contrary to what was proclaimed as an objective during the political transition. Are they right? And what could that tell us about the effects of democratization on distribution?

Redistribution and progressivity are commonplace today in the debate about taxation, but the force of these ideas has changed strongly over history. They were brought by evolving economic thought and political scenarios at the turn of the 20th century, to become gradually accepted by democratic states. However, after the development of Welfare States their validity has been questioned, especially since the economic conditions of the 1970s-80s motivated a stronger emphasis on the disincentive effects of redistributive taxation, an assumed consequence of distributive conflict and social unrest (Alesina and Rodrik, 1994; Persson and Tabellini, 1994). So is redistribution an automatic side effect of inequality, under a democracy? If it were, we would expect the impact of taxes and benefits to change drastically as a result of a regime transition - if this entails an effective modification of power and decision-making institutions, and social preferences support redistribution. In this paper, I investigate the case of Spain during the years surrounding the coming of democracy, to shed some light on the issue.

Empirical investigation on tax incidence has developed since the mid 20th century, with a basic approach still followed today by academia (e.g. Piketty and Saez, 2007) and official statistical institutions. Other studies have focused on public expenditure, or encompassed both aspects (Breceda et al., 2009; Barnard et al., 2011), although many leave aside indirect taxation (e.g. Wang and Caminada, 2011). The literature is wide, but it lacks a common methodological framework and shows no consensus in the relation with political economic variables.

For the case of Spain, most of the available analyses focus on specific taxes (especially the personal income tax; e.g. Onrubia et al., 2007). Some general estimations were performed in the late period of Franco's regime (e.g. Perona, 1972) and also for 1990 (Manresa and Calonge, 2001). Regrettably, these are not directly comparable due to methodological differences: so far, we do not have a long run description of the distribution of the tax burden in the country, to contrast with political events. Obtaining it, and comparing it with other cases, is the primary goal of this paper. The preliminary hypothesis, arising from prior empirical literature and the analysis of the revenue structure, is that the tax system underwent a transition from a regressive to a somewhat proportional system.

This study is necessary for the historical interpretation of the Spanish transition to democracy. As soon as 1977 a broad tax reform was initiated, having among its central goals an improvement in equity. Progressivity and redistribution were explicitly introduced, even in the new Constitution. I analyse to what extent such policy orientation was effectively applied in practice. The main finding is that regressivity was not eradicated from the tax system, although it was attenuated, after having increased during the 1960s. As a result, taxation effected an inverse redistribution of income, contradicting

\footnotetext{
${ }^{3}$ Question posed in surveys by the Centro de Investigaciones Sociológicas, an official sociological research center.
} 
the political discourse and leaving the country far from convergence with the European Welfare State model.

The rest of the paper is organised as follows: section 2 introduces the theoretical framing, and section 3 describes the Spanish tax system and its main reforms. In section 4 I expose the methodology, while section 5 presents the results, ultimately addressing an international comparison. The conclusion sums up the main contributions of the paper and comments on further paths for research on the topic.

\section{Democracy and fiscal redistribution}

Classic political economy models predicted that an extension of franchise would be followed by an increase in redistribution (Meltzer and Richard, 1981). Applied to the theory of political transitions, the basics of the argument are also found in Acemoglu and Robinson (2001) and Boix (2003): democratic countries will be (more?) redistributive, and the threat of such a policy may hinder the achievement or consolidation of democracy.

The logic of these arguments has failed to be consistently backed by empirical work. Aidt and Jensen (2009)'s results pointed to a significant impact of franchise expansion on the adoption of progressive income taxes. Scheve and Stasavage (2012), however, failed to confirm this hypothesis regarding inheritance taxation. On the other hand, the positive impact of democratization has been established for the expenditure side by Lindert (1994), but research examining differences between the socio-economic policies of democracies and non-democracies normally does not get the expected results (Mulligan et al., 2004). ${ }^{4}$

In this regard, a line of literature has called for a nuanced interpretation of political transitions and regimes. Acemoglu et al. (2013) discuss several channels through which democracy may not result in income equalization: increased structural transformation, or the preeminence of the interests of the elite or the middle class. In their empirical exploration, they find no robust effect of democracy on inequality. Albertus and Menaldo (2014) posit that a relationship between democracy and redistribution only arises when a revolutionary threat hampers the elite's control of the democratic transition. Their data, however, measure redistribution only indirectly.

We therefore lack a solid consensus about the effects of democratization on redistribution. This paper proposes Spain as a significant case study. After a four-decade dictatorship, the country underwent a political transition since 1976, accompanied by a profound tax reform that was the basis for the development of the Welfare State and reinforced international integration. However, a historical quantitative study of the distributive changes along the period is still not available.

The interest of the study lies in several points. First, Spain is an example of a peaceful transition: arguably a desirable feature, whose results could be enlightening to compare to other processes. Its political history has many similarities with those of Portugal and Greece, which also suffered dictatorships in the second half of the 20th century, while the rest of Western Europe was under democratic rule. Whether they followed similar paths during and after democratisation could be a good starting point to place the experience analysed here, using Italy as a contrast with longer-standing parliamentary institutions. Several Latin American countries, on the other hand, also experienced recent democratic transitions, though at different levels of economic development and inequality.

The international context is very relevant here: "third wave" democratizations took place at a time of crisis, after the golden age of fordism, growth and redistribution in

\footnotetext{
4 The relationship between inequality and redistribution has also been challenged: while Milanovic (2000) found support for it (leaving aside indirect taxation), other suggest a "Robin Hood paradox", redistribution being more extensive where it is less needed (Lindert, 2004).
} 
Western countries, and surrounded by increasing global integration. This scenario influences the range of policies available. International mobility of assets has been signalled by several scholars as an obstacle to redistribution, given the reinforced leverage of their owners (Bates and Lien, 1985) - and, therefore, as a factor favouring the chances of democratization (Boix, 2003; Freeman and Quinn, 2012).

A specific point of this work is the focus on the revenue side of the budget - although some attention is paid to household benefits as well. Most of the studies in the politicaleconomy tradition have concentrated on disposable income or social expenditure, i.e., indirect or incomplete indicators of redistribution. Tax progressivity, however, is often a social demand in itself, and it is the result of the two-sided budget that matters. Furthermore, the interactions between both dimensions are of interest: in this sense, Timmons (2005) argued that there is a correspondence between the regressivity of taxation and the service to the interests of the poor (leaving little space for effective vertical redistribution), while Steinmo (1989) and Lindert (2004) suggested that more progressive systems tend to be smaller and therefore less redistributive as a whole. To investigate these issues further, better historical data on tax incidence is highly convenient.

To sum up, while early studies suggested a direct relationship between democratization and redistribution, this idea has been elusive empirically and challenged by new theory. The hypothesis of this paper is that the Spanish tax system went from regressivity to nearproportionality during the political transition, thus failing to attain progressivity - which was an explicit objective. This 'insufficiency' affected the redistributive capacity of the joint tax-and-transfer system. The confirmation of these insights would pose our case study as an advocate for the nuanced interpretation of political transitions in the distributive arena.

\section{Reforms and persistence in the tax system}

Two tax systems may be distinguished in modern Spain's history. Both were born in times of political change: in 1845, shortly after parliamentary politics stabilized under dominance of the moderate party; again in 1977, as Franco's dictatorship gave way to a new parliamentary regime. This coincidence provides a motivation for the paper, following Schumpeter's insight that "The public finances are one of the best starting points for an investigation of society, especially though not exclusively of its political life" (Schumpeter, 1954).

The main features of the 1845 system were the predominance of indirect taxes (especially excises), the design of direct taxation as factor-specific taxes, ${ }^{5}$ and a scarce revenue potential, tending to stagnate (Comín, 2010b). The structure was completed in the turn of the century adding taxes on capital and labour; further changes did not affect the fundamentals of the model (Comín and Martorell, 2013). Nearest to our period, Navarro Rubio's reforms in 1957 and 1964 were related to a major turn in economic policy: the abandonment of autarchic orientation with the 1959 Stabilization Plan. ${ }^{6}$ The first reform pursued an increase in revenues, together with the extension of incentives to investment, while in 1964 the alleged objective was redistributive; however, in spite of the propaganda, redistribution did not find its way under the dictatorship.

\footnotetext{
5 This taxation is directed upon each specific source of income regardless of the taxpayer's characteristics, as opposed to personal taxation, which aims to jointly consider economic capacity from all sources.

${ }^{6}$ A deflationary programme put forth in time of critical economic imbalances, meant to start internal and external liberalization.
} 
Despite the lack of fundamental tax reform, there were some significant changes in the financing of public administrations in Franco's Spain. Social Security was introduced in a 1963 law as the result of integration of different social insurance programs, taking off in practice in 1967 (Comín, 2010a). ${ }^{7}$ As a consequence, in the final years of the dictatorship public budgets did grow noticeably, but without a (politically complicated) 'tax' reform, using an independent contributory system that increased pressure on labour. Figure 1 shows the share of social contributions in total tax revenue progressively growing during late Francoism, to become the main source of funding in the beginning of the 1970s. The shares of direct and indirect taxation got closer over these years, with both lines almost coinciding since 1978. This was an objective of the reform, but for its implications in terms of progressivity a deeper analysis is required.

Figure 1: Main categories as \% of total Spanish tax revenue

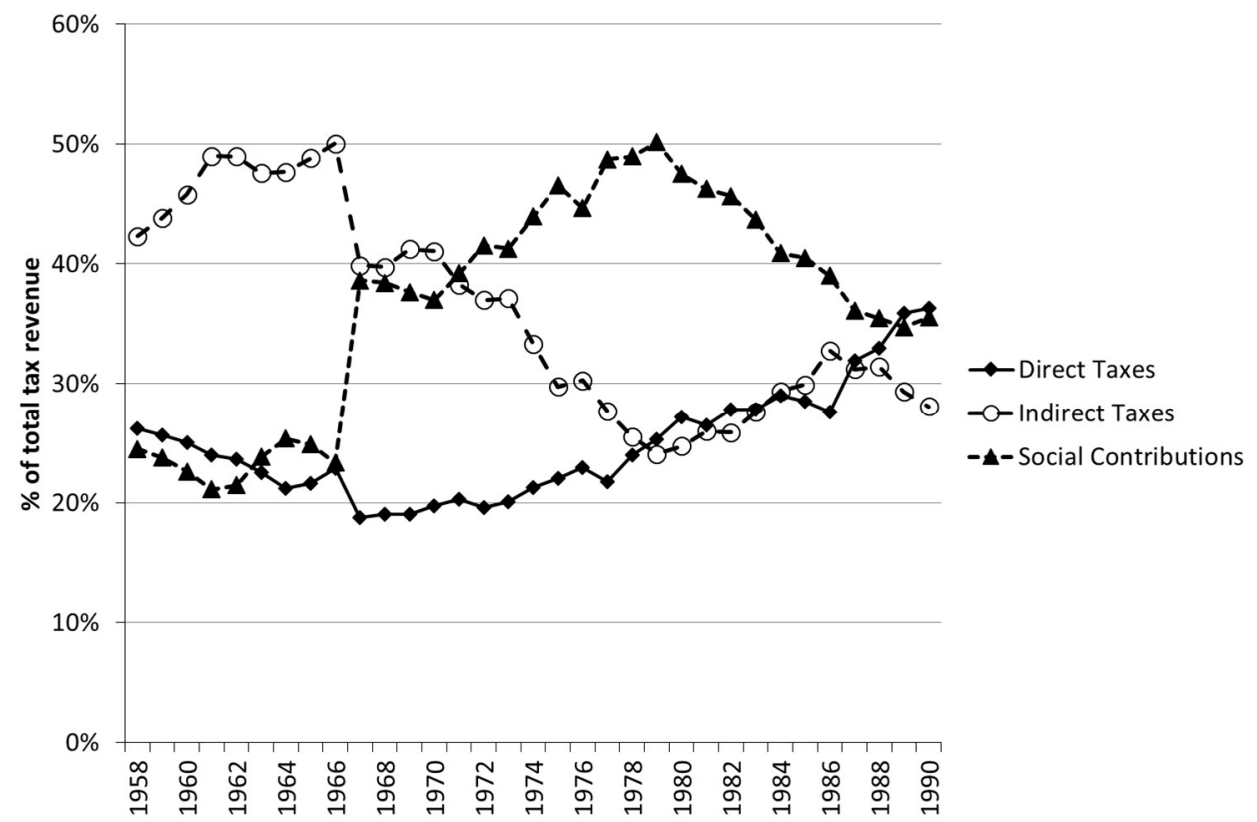

Source: Cuentas de las Administraciones Públicas (see the online Appendix A).

The first vertical line represents the discontinuity in the series in 1967 , due to the coming into force of the 1963 Social Security law; the second one marks the reform year 1978.

Transition to democracy brought about a comprehensive transformation of the tax system, thought of as a basic aspect of the regime change. The main political parties shared the core of a reform program put forward by the Institute for Fiscal Studies, a center of studies related to the Ministry of Public Finance (Instituto de Estudios Fiscales, 1973): it aimed at attaining a balance between direct and indirect taxes, thus improving the fairness of the system, and at increasing revenue to finance the development of the Welfare State in response to social demands. All this meant a convergence with the European model. It

\footnotetext{
${ }^{7}$ In this paper Social Security contributions will be considered as a tax. This is based on the extent to which the system functions as an insurance or not: compulsory or voluntary nature, the level of budgetary autonomy, the actuarial or pay-as-you-go administration, the proportionality between contributions and benefits, or the existence of non-contributory pensions. Bandrés and Cuenca (1996) showed that in 1992 the 'transfer' component in Spanish public pensions was around 50\% of the benefit received, and not homogeneous across professional regimes, so the tax-benefit approach is justified.
} 
was made possible only a few years after Franco's death, as part of the negotiations in the Moncloa Pacts. ${ }^{8}$

As an immediate effect, the new personal income tax (hereafter, PIT) substituted a progressive structure for the previous range of factor taxes, and became central in public revenues, unlike its old precedents. A Wealth tax was introduced during the same years, but always provided a small share of the public budget, as did the Inheritance tax. Social contributions also experienced changes in the contributory scheme and administrative reorganisation. The consensus period, however, did not last long, and gave way to what some have called the "fiscal counter-reform" (Pan-Montojo, 1996). The culmination of projected changes was delayed, especially in indirect taxes: VAT was not introduced until 1986, at the time of accession to the European Economic Community, replacing a Transactions tax and the Luxury tax. Generally, indirect taxation followed the lead of international integration and harmonization in the construction of the common market (also affecting excises, public monopolies and tariffs). ${ }^{9}$

After 1978 public budgets experienced a significant expansion, which funded the nascent Welfare State (together with an increase in public deficits). The process of convergence with more advanced countries remained nevertheless incomplete: as shown in figure 2, total tax revenue in terms of GDP approached that of the EU core, but a significant differential stayed in place, and the path was reversed by the economic crises of the early 1990s' and 2008, indicating its vulnerability (a somewhat different story would arise if our reference were other OECD countries, which Spain has slightly surpassed). Understanding the unfinished convergence with Western Europe's model will require taking into account the regime transition in Spain together with the change in economic conditions since the original development of Welfare States. The oil shocks and the turn taken by economic policies in the eighties moved emphasis from equity to efficiency.

Since 1990 no global redesign has been undertaken, although partial modifications have been abundant, affecting PIT $(1991,1998,2006)^{10}$, the corporation tax $(1995,2006)$ and VAT $(1992,1995,2010,2012)$. Increases in VAT rates have several times been implemented in conjunction with reductions in social security contributions. The democratic period also involved decentralisation in favour of regional governments, both of expenditure and revenue. This process finally entailed the transfer of regulatory capacities in 1996, which brought about a partial differentiation among regions and a "race to the bottom" in some cases like the Inheritance tax (Durán and Esteller, 2010). Was there a transition into progressivity as a result of these changes? In spite of the stated objectives and the classic political economy models, aspects such as the constantly high share of social contributions or the more intense taxation of wages and salaries in PIT (related to the bigger possibilities of fraud in other sources) sustain our hypothesis of a still regressive or near-proportional incidence in 1990, as Manresa and Calonge (2001) obtained. This culmination of the tax reform process is not consistent with the discourses emanating from the government, nor with the most extended opinion among citizens about fairness in taxation. ${ }^{11}$

\footnotetext{
${ }^{8}$ Agreements reached in the autumn of 1977 by the main political parties. They focused on setting a policy response to the economic crisis, but included also several points on taxation (Comín, 2007).

9 Tariffs had a considerable importance in the sixties (a common feature of underdeveloped countries), lost due to commercial liberalization. State monopolies, banned by EU legislation, were replaced by excises.

${ }^{10}$ Introduction of optional separate filing for married couples in 1989, modifications in the allowance structure in 1998, partial dualization in 2006.

${ }^{11}$ I follow Alvira and García (2005) in this aspect, but we lack more specific information on public attitudes towards progressivity.
} 
Figure 2: Tax revenue as percentage of GDP

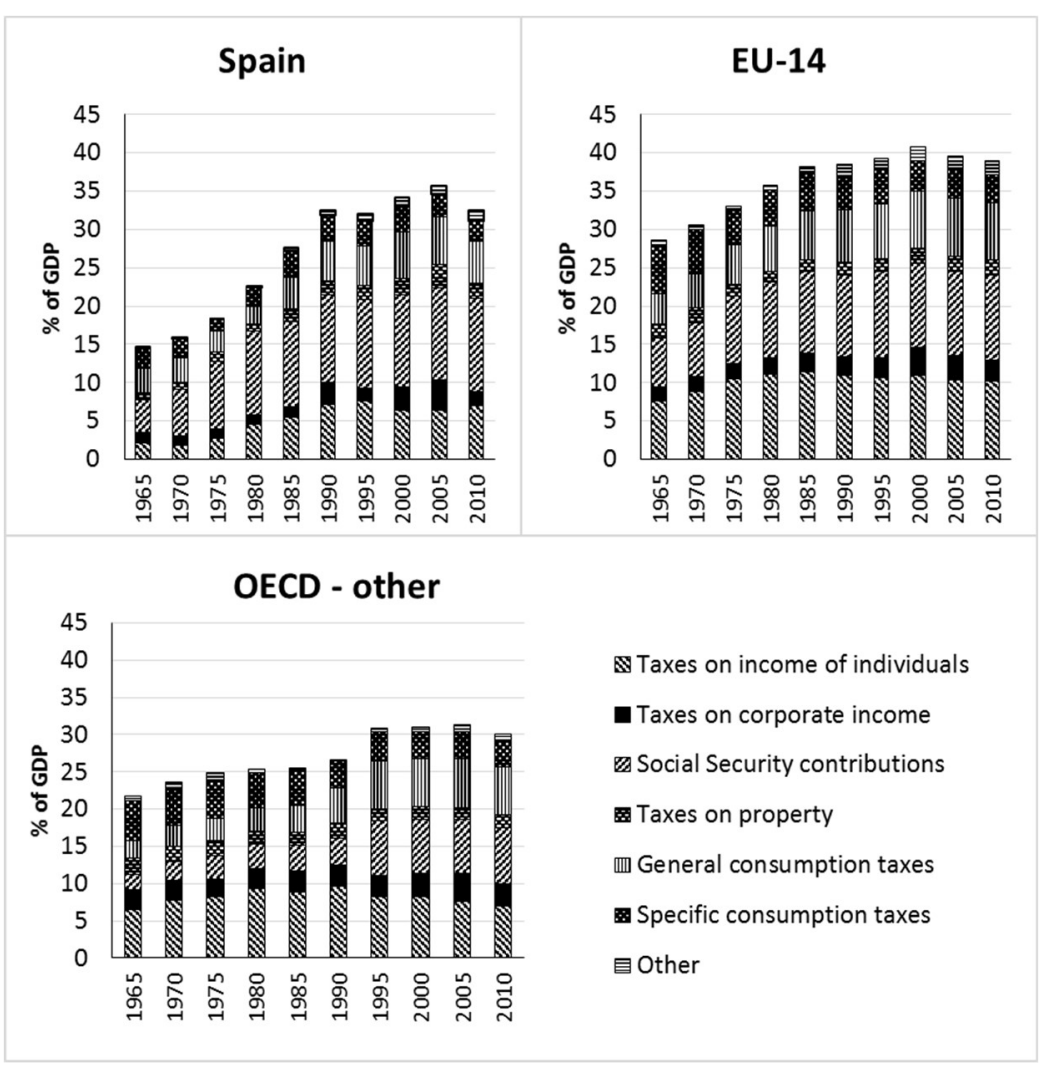

Source: OECD Statistics (unweighted average). EU-14: European Union of 15 members excluding Spain. OECD-other excludes all EU-15 countries.

The "OECD-other" series is not homogeneous over time, since prior to 1995 data is not available for a number of countries (Chile - pre-1990, Czech Republic, Estonia, Hungary, Israel, Korea -1972, Poland, Slovak Republic, Slovenia).

\section{Calculating progressivity}

Tax incidence analysis proceeds by imputation of tax revenue to the social groups assumed to have borne the corresponding burden (Fullerton and Metcalf, 2002). I use the results of previous theoretical and empirical literature to assign tax payments and obtain effective tax rates by percentiles, and indices of progressivity and redistribution. ${ }^{12}$ The methodology is briefly reviewed here; for further details, see Appendices B and C.

Some limitations of this work are the uncertainty on the economic incidence of several taxes and the non-inclusion of possible dynamic effects. ${ }^{13}$

${ }^{12}$ Progressivity is the increase in the tax rate as income grows, while redistribution is the difference in inequality caused by taxation.

${ }^{13}$ For a discussion on the latter, see Onrubia et al. (2005). 


\subsection{Time span of the analysis}

I have chosen the years 1970, 1982 and 1990 as representative of the evolution of the tax system during these decades, spanning from the latter years of Franco's regime to after the consolidation of democracy. ${ }^{14}$

The analysis is annual all along. A strand of literature has considered that due to income variability across the life-cycle, tax incidence is best analysed with yearly taxes on "permanent income" or in a lifetime perspective. Both are choices not taken here, because of a rejection of the underlying assumptions of perfect capital markets and unchanged tax policy, together with the hard data constraint we face and the fact of wanting to include in the analysis the income-smoothing dimension. ${ }^{15}$

\subsection{Incidence hypotheses}

As is well known, the long-term economic incidence of taxes does not necessarily coincide with the legal one. I have only considered one hypothesis regarding income, wealth and consumption taxes, since there is quite a wide consensus about their real incidence in applied literature. On the other hand, alternative possibilities are calculated for the most controversial cases: social contributions, the corporation tax and real estate taxes (see table 1).

Table 1: Tax incidence hypotheses

\begin{tabular}{lc|c} 
& BASELINE & ALTERNATIVES \\
\hline $\begin{array}{l}\text { Income } \\
\text { Wealth }\end{array}$ & No shifting & - \\
\hline Real Estate & No shifting & - \\
\hline Social Contributions & Occupier & $50 \%$ Owner - 50\% Occupier \\
\hline & Worker & $\begin{array}{c}50 \% \text { Worker - 25\% Employer - } \\
25 \% \text { Consumption }\end{array}$ \\
Corporate & $34 \%$ Capital - & b) $30 \%$ Capital - $70 \%$ Labour \\
& $33 \%$ Labour - & c) $70 \%$ Capital - $30 \%$ \\
& $33 \%$ Consumption & Consumption \\
\hline Consumption & Consumer & - \\
Stamp Duties & Purchaser & - \\
\hline \hline Source: Author
\end{tabular}

Source: Author's compilation.

The estimation of tax payments consists in allocating the revenue of each tax using the distribution of the corresponding tax base across households. It generally relies on the implicit assumption that fraud is uniformly distributed (not that it is non-existent, given the use of real tax revenue instead of legal simulation according to income). This has been a necessary simplification. It may be argued that the direction of the bias is an overestimation of progressivity, because tax evasion was historically concentrated on high incomes (Comín et al., 1995) and in recent work it has been found to be more extended in capital and self-employment incomes (Domínguez et al., 2013; Torregrosa, 2014a).

\footnotetext{
14 The choice of 1982 is due to the availability of PIT micro-data starting then: "PANEL PURO Y EXTENDIDO IRPF 1982/1998 IEF-AEAT (Declarantes)".

15 The lifetime analysis would allow disentangling interpersonal from inter-temporal redistribution, its results corresponding only to the first one (Bengtsson et al., 2012).
} 


\subsection{Data and income concepts}

To make the results representative for the whole of the tax system, I use data from all Public Administrations: central State, Social Security and sub-central governments (accrual basis). A complete list can be found in the online Appendix A. Non-tax public revenue is not included.

Regarding the distribution of tax bases, I employ the Household Budget Surveys (HBSs) conducted by the National Statistical Institute. They have been previously adjusted to National Accounts to reduce their well-known under-reporting problem and potential bias (Torregrosa, 2014b). ${ }^{16}$ Income is used to impute tax payments and also as an indicator of economic capacity by which to rank households. The following phases are distinguished:

- PRE-TAX INCOME = Gross Monetary Income (Net Monetary Income + Factor Taxes \& Social Contributions) + Imputed Income (Self-production + Owneroccupied housing)

- NET FACTOR INCOME = Pre-Tax Income - Factor Taxes \& Social Contributions

- $\quad$ POST-TAX INCOME $=$ Net Factor Income - Consumption Taxes

- DISPOSABLE INCOME = Net Factor Income + Public Benefits + Private Transfers

- POST-TAX-AND-TRANSFER INCOME = Disposable Income - Consumption Taxes

A word has to be said about public benefits. The capitalization component in them corresponds to Pre-tax income, while the redistributive part is a transfer from the State and belongs only to Disposable income. It is out of the scope of this paper to distinguish among both: I have considered all the amount as transfers. ${ }^{17}$ Nonetheless, an alternative estimation is performed in the online Appendix F placing pensions as part of Pre-tax income.

\subsection{Indicators}

- Average Effective Tax Rates by income range:

$$
A E T R=\frac{\sum_{h=1}^{n}\left(\frac{T_{h}}{Y_{h}}\right) W_{h}}{\sum_{h=1}^{n} W_{h}}, h=1 \ldots n ;
$$

where $T_{h}$ is total tax payments by household $h, Y_{h}$ her total pre-tax income, $W_{h}$ her weight in the calculation (product of sampling weight $\varrho$ and the household's real size $S_{h}$ ), and $n$ is the total number of households in the range. If the profile of AETR is increasing in income, the tax (system) is progressive.

- Kakwani index: progressivity indicator, obtained as the difference between the concentration of tax payments $C_{T}$ and the Gini of Pre-tax income $G_{Y^{\circ}}$

$$
K=C_{T}-G_{Y}
$$

\footnotetext{
16 There are no micro-data available from the first 1964 survey.

17 Recall the findings of Bandrés and Cuenca (1996).
} 
It takes value 0 for a proportional tax, positive for a progressive one.

- Reynolds-Smolensky index: redistribution indicator. $G_{Y}$ being the Gini index for Pre-Tax income and $G_{Y-T}$ the corresponding Gini for Post-tax income, it is defined as:

$$
R S=G_{Y}-G_{Y-T}
$$

A tax is redistributive if $R S>0$. This change in inequality can be decomposed as follows:

$$
G_{Y}-G_{Y-T}=\left(G_{Y}-C_{Y-T}\right)-\left(G_{Y-T}-C_{Y-T}\right)=V E-R R
$$

where $C_{Y-T}$ is the concentration of Post-tax income with households ranked by Pre-tax incomes. $V E$ captures the Vertical Effect (redistribution among households with their ranking fixed) and $R R$ is Re-Ranking (if households get re-ordered, $V E$ overestimates (underestimates) the decline (increase) in inequality caused by taxation). ${ }^{18}$

I take equivalent pre-tax incomes as a reference for all calculations. ${ }^{19}$ Since between the different scenarios both the base distribution and tax regulations change, the evolution in all indices is a joint effect. The same issue, of course, is present when comparing tax systems in different countries.

\section{Results}

There is not enough information to include the 1960s in the main estimation, but some conclusions are allowed. Regressivity probably increased during the decade due to two concurrent changes: the growth in indirect taxes relative to direct ones, and the development of social contributions. See the online Appendix E.

\subsection{The tax system between 1970 and 1990}

Average Effective Tax Rates by deciles are shown in tables 2, 3 and 4. The top is further disaggregated, because of the huge dispersion in it, and the fact that these taxpayers concentrate a significant portion of total income and tax payments.

In all tables, total tax rates faced by households are bigger in the first deciles that in the upper ones. Rates estimated for the lower levels of income are very high, even above $100 \%$ in some cases, because there are households with very scarce or null market income. But leaving the first decile aside, the downward slope is still present all over the period: from the second to the tenth deciles, in 1970 the AETRs go from $28 \%$ to $20 \%$, in 1982 from $45 \%$ to $35 \%$ and in 1990 from $72 \%$ to $46 \%$. The tax system was regressive, placing more burden on low-income classes. This conclusion is also clear at the tail of the distribution: the top $1 \%$ paid $16 \%$ of their pre-tax income in taxes in $1970,33 \%$ in 1982 and $45 \%$ in 1990 - i.e., significantly below the rates faced at the bottom.

\footnotetext{
18 All indices have been calculated in Stata, using the 'progres' module (Peichl and Van Kerm, 2007).

19 Making a sequential analysis is misleading, since the order of the calculations has an impact on the results; many taxes are simultaneously paid, so it would be an arbitrary choice. This point is made by Onrubia et al. (2014).
} 
This result was driven by social contributions and consumption taxes. The latter fell overwhelmingly on the poor in spite of mitigating aspects such as the Luxury tax or the different tax rates in VAT. This feature is an unsurprising effect of consumption being less unequally distributed than income. Over disposable income (last column of each table) the rates appear less markedly decreasing, but are still so because of the different propensities to save and consume.

Table 2: Average Effective Tax Rates in 1970

\begin{tabular}{lcccc|c} 
& Direct & Social & & Indirect \\
over \\
Disp. \\
Decile 1 & & Contributions & & Total & 11.01 \\
Decile 2 & 11.31 & 5.94 & 87.21 & 104.51 & 12.39 \\
Decile 3 & 3.58 & 11.48 & 13.49 & 28.46 & 11.89 \\
Decile 4 & 3.73 & 12.79 & 11.61 & 27.96 & 11.63 \\
Decile 5 & 3.77 & 12.78 & 10.87 & 27.38 & 11.58 \\
Decile 6 & 3.96 & 11.35 & 10.62 & 26.14 & 11.00 \\
Decile 7 & 4.04 & 10.67 & 9.60 & 25.32 & 10.67 \\
Decile 8 & 4.25 & 9.29 & 9.22 & 24.33 & 10.21 \\
Decile 9 & 4.57 & 7.88 & 9.33 & 22.77 & 10.28 \\
Decile 10 & 5.77 & 5.83 & 8.13 & 19.73 & 8.91 \\
\hline \hline Top 5\% & 6.57 & 4.79 & 7.41 & 18.76 & 8.07 \\
Top 1\% & 8.54 & 2.56 & 5.00 & 16.05 & 5.44 \\
\hline \hline
\end{tabular}

Source: Author's calculations.

Deciles of individuals ranked by Equivalent pre-tax income. Pre-tax household income is the denominator in all except the last column.

'Direct' includes all taxes paid on income and wealth (of which the main are the Corporation tax and the Labour tax), 'Social Contributions' includes those of employers, workers, civil servants and the self-employed. 'Indirect' means taxes incurred in the consumption of goods and services (the main being Tariffs, the Luxury tax and the General Sales tax). For a complete list, see the online Appendix A.

Table 3: Average Effective Tax Rates in 1982

\begin{tabular}{lcccc|c} 
& Direct & $\begin{array}{c}\text { Social } \\
\text { Contributions }\end{array}$ & Indirect & Total & $\begin{array}{c}\text { Indirect over } \\
\text { Disp. Income }\end{array}$ \\
\hline Decile 1 & 18.99 & 11.12 & 95.52 & 125.64 & 7.60 \\
Decile 2 & 5.98 & 21.94 & 17.35 & 45.28 & 10.26 \\
Decile 3 & 6.77 & 18.02 & 11.63 & 36.43 & 10.77 \\
Decile 4 & 7.53 & 17.69 & 10.51 & 35.72 & 11.26 \\
Decile 5 & 8.03 & 17.48 & 9.40 & 34.91 & 10.76 \\
Decile 6 & 8.35 & 17.95 & 9.34 & 35.64 & 11.23 \\
Decile 7 & 8.74 & 17.85 & 8.64 & 35.24 & 10.72 \\
Decile 8 & 9.13 & 17.97 & 8.18 & 35.29 & 10.40 \\
Decile 9 & 9.45 & 18.43 & 7.43 & 35.31 & 9.67 \\
Decile 10 & 12.20 & 15.94 & 6.43 & 34.56 & 8.61 \\
\hline \hline Top 5\% & 13.90 & 14.05 & 6.17 & 34.11 & 8.27 \\
Top 1\% & 18.39 & 9.68 & 4.59 & 32.66 & 6.21 \\
\hline \hline
\end{tabular}

Source: Author's calculations.

Deciles of individuals ranked by Equivalent pre-tax income. Pre-tax household income is the denominator in all except the last column. 
'Direct' includes all taxes paid on income and wealth (of which the main are PIT and the Corporation tax), 'Social Contributions' includes those of employers, workers, civil servants and the self-employed. 'Indirect' means taxes incurred in the consumption of goods and services (the main being the General Sales tax, Excises and Tariffs). For a complete list, see the online Appendix A.

Regarding social contributions, their burden was largely determined by the distribution of salary income, but not proportionally. The amount to be paid was up to 1972 assessed upon a legal base set for ten categories in the workforce, with a regressive effect. During the seventies reforms brought the base progressively closer to real salaries, but never fully. Since 1977, the taxable base is the salary (but not all of its components) up to an upper cap for each category, which still distorts proportionality for the better paid

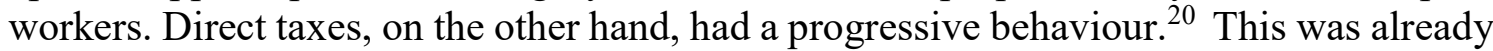
true in 1970, albeit slightly (the tax rate faced by the top decile was near $6 \%$ while for almost all the rest it laid under 4.5\%); much more so in 1982 and 1990 (top decile rates had gone up to $12 \%$ and $21 \%$ respectively). This shows the effects of the reform undertaken during the political transition. Several works had already established the progressivity of PIT, the central tax in this category (e.g. Onrubia et al., 2007).

Table 4: Average Effective Tax Rates in 1990

\begin{tabular}{lcccc|c} 
& Direct & $\begin{array}{c}\text { Social } \\
\text { Contributions }\end{array}$ & Indirect & Total & $\begin{array}{c}\text { Indirect over } \\
\text { Disp. Income }\end{array}$ \\
\hline Decile 1 & 43.83 & 8.94 & 181.98 & 234.76 & 17.32 \\
Decile 2 & 17.02 & 19.04 & 35.69 & 71.76 & 21.23 \\
Decile 3 & 13.14 & 18.42 & 21.88 & 53.45 & 20.24 \\
Decile 4 & 12.96 & 19.68 & 18.35 & 50.99 & 20.43 \\
Decile 5 & 13.52 & 19.60 & 16.42 & 49.54 & 19.40 \\
Decile 6 & 13.71 & 19.25 & 14.23 & 47.19 & 18.00 \\
Decile 7 & 14.59 & 19.13 & 13.54 & 47.26 & 17.48 \\
Decile 8 & 15.49 & 18.72 & 12.87 & 47.07 & 17.30 \\
Decile 9 & 16.60 & 17.99 & 10.82 & 45.41 & 14.85 \\
Decile 10 & 20.73 & 16.03 & 9.38 & 46.14 & 13.65 \\
\hline \hline Top 5\% & 22.48 & 14.95 & 7.89 & 45.33 & 11.72 \\
Top 1\% & 31.35 & 8.53 & 5.35 & 45.23 & 8.22 \\
\hline \hline
\end{tabular}

Source: Author's calculations.

Deciles of individuals ranked by Equivalent pre-tax income. Pre-tax household income is the denominator in all except the last column.

'Direct' includes all taxes paid on income and wealth (of which the main are PIT and the Corporation tax), 'Social Contributions' includes those of employers, workers, civil servants and the self-employed. 'Indirect' means taxes incurred in the consumption of goods and services (the main being VAT and Excises). For a complete list, see the online Appendix A.

Progressivity and redistribution indices in table 5 confirm and clarify these observations. The tax system became less regressive (the Kakwani index is negative, but its absolute value got smaller), due to the reform in direct taxation and the changes in the Social Security contributory system. On the other hand, indirect taxes became more regressive, even during the seventies in the absence of significant reform. Such a result can be attributed to some extent to changes in the underlying structure of consumption: more households started consuming items subject to Luxury tax, and a reduction in

20 The first decile is an exception, as a result of low pre-tax incomes combined with the shifting of real estate and corporation taxes on the prices of goods. 
expenditure inequality (favoured by the development of State benefits in the second subperiod) paradoxically had the same effect. ${ }^{21}$ Combined tax regressivity was mitigated but persisted, being more intense at both ends of the income distribution.

AETRs for each category are displayed in the second row to show how direct taxation was powerless to impact positively on the income distribution, when compared to the weight of the other components. Social contributions grew a lot, and consumption taxes were reinforced in 1986: the regressive elements outdid the progressive ones. All in all, this means that taxation effected an inverse redistribution not only in 1970 but also in 1982 and 1990, in the first years of the new parliamentary regime and after it was consolidated. The Reynolds-Smolensky index became larger in absolute value, because of the increase in the tax burden: in 1970 taxation increased the Gini index in around 3.4 points, 2.6 in 1982, and 6.9 in 1990. These results seem unexpected at first sight. They are at odds with the stated objectives of the reform and the equalization demands we would expect a democratic country to fulfil. There was no fiscal revolution: we can confirm our hypothesis about the transition not sustaining a deep enough change in tax incidence. The first stage of the reform, that of direct taxation, was quite successful in expanding redistribution, but faced some significant obstacles (notably persistent tax evasion). The original joint plan, moreover, did not get fulfilled. It included, among other, new inheritance and wealth taxes and the introduction of VAT: these further developments were not possible after the breaking of the initial consensus period around 1979 - after the Constitution had been passed the year before. The tax reform is connected to the crisis of the governing UCD (Unión de Centro Democrático, Suárez's party), which ultimately led to its division and loss of electoral support. Internal and external criticism from the right was becoming intense. ${ }^{22}$ A prominent role was played by the entrepreneurs' association CEOE (Confederación Española de Organizaciones Empresariales), lobbying for policies in favour of savings and private investment.

Table 5: Progressivity and redistribution over the period

\begin{tabular}{|c|c|c|c|c|}
\hline \multicolumn{5}{|c|}{1970} \\
\hline & Direct & Soc. Contr. & Indirect & Total \\
\hline K & 0.0974 & -0.1466 & -0.1277 & -0.0892 \\
\hline AETR & 4.77 & 8.89 & 9.73 & 23.39 \\
\hline $\mathrm{RS}$ & 0.0047 & -0.0169 & -0.0162 & -0.0344 \\
\hline \multicolumn{5}{|c|}{1982} \\
\hline & Direct & Soc. Contr. & Indirect & Total \\
\hline $\mathrm{K}$ & 0.1137 & -0.0434 & -0.1783 & -0.0304 \\
\hline AETR & 10.26 & 16.84 & 8.53 & 35.63 \\
\hline $\mathrm{RS}$ & 0.0126 & -0.0138 & -0.0180 & -0.0258 \\
\hline \multicolumn{5}{|c|}{1990} \\
\hline & Direct & Soc. Contr. & Indirect & Total \\
\hline
\end{tabular}

${ }^{21}$ The Gini index for total consumption among individuals was 35.09 in 1970 and had gone down to 33.13 by 1982 and 32.06 by 1990 . Increasing regressivity in indirect taxation was already observed by Argimón et al. (1987).

${ }^{22}$ In the words of L. Calvo Sotelo, prime minister in 1981-82: "Fernández Ordóñez and his tax reform attracted very soon the anger of the right: 'You are making left-wing politics with votes you got from the right'”' (Calvo Sotelo, 1990, p. 163). A similar perception is transmitted by E. Fuentes Quintana (architect of the reform, Vice-president of the government and Minister of Economic Affairs in 197778), in an interview published in the 1990s: "The reform measures were effectively stopped. A big part of the tax changes were paralysed by vested interests” (Fuentes Quintana, 2004). 


\begin{tabular}{ccccc}
$\mathrm{K}$ & 0.0823 & -0.046 & -0.2337 & -0.0520 \\
$\mathrm{AETR}$ & 17.53 & 17.38 & 13.53 & 48.44 \\
$\mathrm{RS}$ & 0.0151 & -0.0137 & -0.0413 & -0.0694 \\
\hline \hline
\end{tabular}

Source: Author's calculations.

Pre-tax equivalent incomes, weighting by household size.

This scenario inspired the term "fiscal counter-reform" (Pan-Montojo, 1996). The initial phase of consensus in the critical moments of the transition was followed by increased organization and lobbying capacity in the right (employers' unions and growth of the right-wing party Alianza Popular). The elections in 1982 brought to government the social-democratic party PSOE (Partido Socialista Obrero Español): it would stay until 1996, culminating some aspects of the plan. In this sense, table 3 represents the first phase of tax developments, and table 4 the results of the first PSOE administrations.

During this period, however, the political and economic context had changed, with support for progressivity considerably weakened. Significantly, the adjustments made in the PIT schedule during the eighties reduced the number of brackets and cut down top marginal tax rates. This makes it difficult to read changes in tax incidence as a reflection of strongly opposed party positions. Indirect taxation was not only modernized but also reinforced, specially affecting the lower classes, at the same time that Welfare state transfers and services were expanded. ${ }^{23}$

To directly assess the effects of taxation (and transfers) on inequality, table 6 displays the Gini index for the previously defined income phases. The difference between pre-tax and post-tax income Gini indices equals the $R S$ index shown above. In 1970, even factor taxes caused inequality to increase (difference between columns 1 and 2), while in the later years the improvement in the redistributive effect of direct taxation comes trough. The general impact on Post-tax incomes, nevertheless, is still negative: what the tax system did in one phase, it undid in the following.

Table 6: Taxation and income inequality (Gini index)

PRE-TAX NET F.I. POST- DISP.I. P-TRANS

TAX

\begin{tabular}{rrrrrr}
\hline 1970 & 37.92 & 38.99 & 41.36 & 34.66 & 36.19 \\
\hline 1982 & 41.94 & 41.51 & 44.51 & 32.96 & 34.49 \\
\hline 1990 & 42.23 & 40.83 & 49.17 & 32.88 & 37.26 \\
\hline \hline
\end{tabular}

Source: Author's calculations.

Equivalent income, weighted by household size. 'P-TRANS' stands for Post-tax-andtransfer income.

Of course, this does not mean that the overall effect of the public sector towards the lower classes was extractive. Welfare State development was the other side of the coin to this augmented taxing power. Benefits were extended and public education and health systems were funded, so the expenditure side of the budget allowed for improvements in income distribution and towards equality of opportunity. I turn to this now.

\footnotetext{
${ }^{23}$ This evolution can be related to the previously mentioned insights of Timmons (2005) about the correspondence in both sides of the budget, or Lindert (2004) in that tax progressivity and fiscal redistribution need not go hand in hand.
} 


\subsection{Considering the effect of benefits}

Table 6 shows that the distribution of disposable income decreased very slightly in the period, as was obtained in Torregrosa (2014b). Disposable income is the result of adding to net factor incomes both public and private transfers (they are not disaggregated in the HBSs until 1990). These flows caused a decrease in inequality of around 4 Gini points in 1970, 8.5 in 1982 and 8 in 1990 (difference between columns 2 and 4). So, what the fiscal system did in one phase, it undid in the following? ${ }^{24}$

Post-tax-and-transfer income is the net result of all these flows, the inequality finally existing in the country in terms of net consumption capacity. The total tax-benefit system had an equalizing effect (respectively, 1.7, 7.5 and 4.5 Gini points in 1970, 1982 and 1990). This final income has grown more unevenly distributed over the decades under study, but considerably less than market incomes (1.07 vs. 4.3 Gini points).

Figure 3 tries to cast some further light on the issue, by plotting tax rates that include transfers as a negative tax. Here, percentiles with positive rates are net contributors: approximately the upper $70-75 \%$ of individuals. The ones with rates under zero, on the contrary, received more money than they paid in taxes. These rates are growing with income, entailing that the joint fiscal system did provide redistribution (as was shown above).

The fiscal system in 1970 was clearly less progressive than in later years, since the profile is flatter and the line crosses 0 earlier (i.e., households being net contributors back then were poorer than their counterparts in the following decades, both in relative and in absolute terms). Among net-recipient households, the rates were lower in 1982 than in 1990. This is presumably an effect of the increase in tax rates for the poorer families which followed the introduction of VAT, thus reinforcing the convenience of analysing together the distribution of tax payments and what they are financing. ${ }^{25}$ At the top, where in 1970 we find a negative-slope stretch, in the next years there is a flat plateau or slightly increasing rates. The change is significant, but progressivity was rather weak after the middle of the income scale.

These calculations do not include in-kind benefits (mainly, health and education), which are also inequality-reducing. Thorough approaches to the incidence of total social public expenditure can be found in the literature. According to Bandrés (1993), in-kind social expenditure would have reduced the Gini index in 3.61 points in 1980; 3.99 in 1994 following Calero (2001). These impacts are in any case smaller than those of monetary benefits, which stand between 6 and 15 Gini points in the same studies. ${ }^{26}$

It can therefore be said that the public sector as a whole impeded the increase in marketgiven inequality to be completely translated onto post-tax-and-transfer incomes. But it certainly does not seem to have done so by means of the tax system, and did not manage to effectively counteract the trend of rising inequality.

${ }^{24}$ In 1990, public benefits were $89.5 \%$ of total transfers received by households according to the HBSs. This percentage was likely lower in earlier years, so "redistribution" shown by the Gini indices would be overestimated, with the bias probably decreasing over time.

${ }^{25}$ In fact, and quite surprisingly, if we compare the mean of post-tax-and-transfer real incomes by deciles between 1982 and 1990 we can see that the poorest households actually lost net purchasing power during the decade.

26 The cited works make an imputation of monetary public transfers that goes far beyond my simple exercise above. Regrettably, their results are not readily integrated with mine because of methodological differences. 
Figure 3: Average Effective Tax-and-Transfer Rates
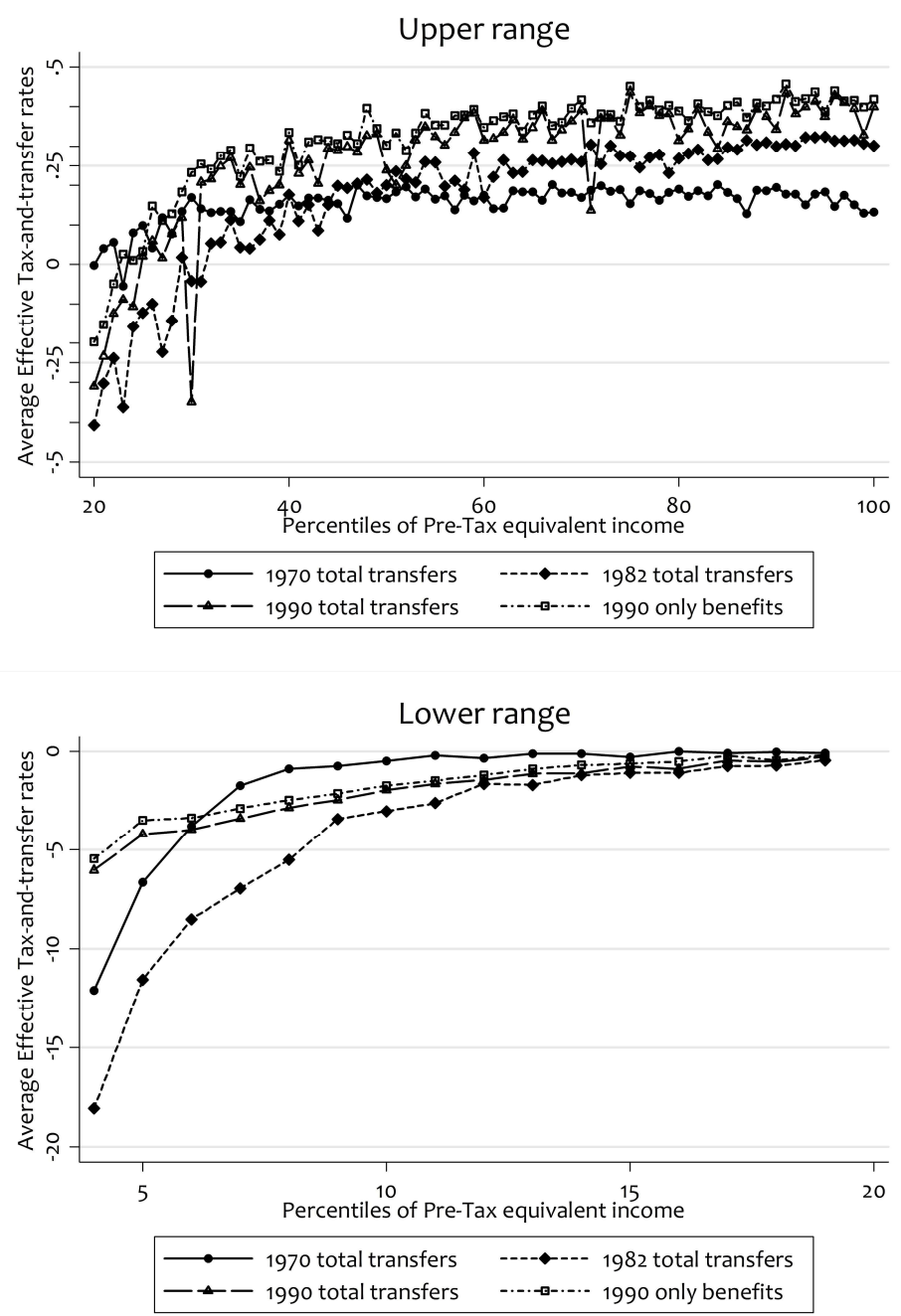

Source: Author's calculations.

The lowest percentiles are not included because of their extreme values. For 1990 I include two calculations: one with the total (comparable to the previous years) and one considering only public benefits (a better representation of the tax-and-transfer system in place).

\subsection{How different was Spain from other countries?}

The international comparison will show if the objective of convergence with the developed European neighbours was attained, and will also contrast this experience with that of other countries with similar or differing political histories. The following discussion is however deeply dependent on the availability of comparable calculations: studies on income redistribution are often not general, but focused on PIT (often along with social contributions) and household benefits.

The first question is whether Spain converged to the developed countries, taken as a model at the time of the reform. In order to investigate the issue, figure 4 plots direct 
AETRs (including social contributions) for the United States, Sweden, the United Kingdom, France and Spain (UK and France only available in 1970). ${ }^{27}$

Spain stands out for its regressivity in 1970 and 1982. There is partial convergence, driven by changes in both sides: loss of progressivity in Sweden and the US combined with the opposite path in Spain, which by 1990 had near-proportional direct taxation. Higher rates had arrived first to the middle-upper class and later - incompletely - to the top. The evolution towards progressivity, delayed by the dictatorship, did not fully reach the levels seen in these other countries.

Figure 4: Direct Tax Rates. International comparison
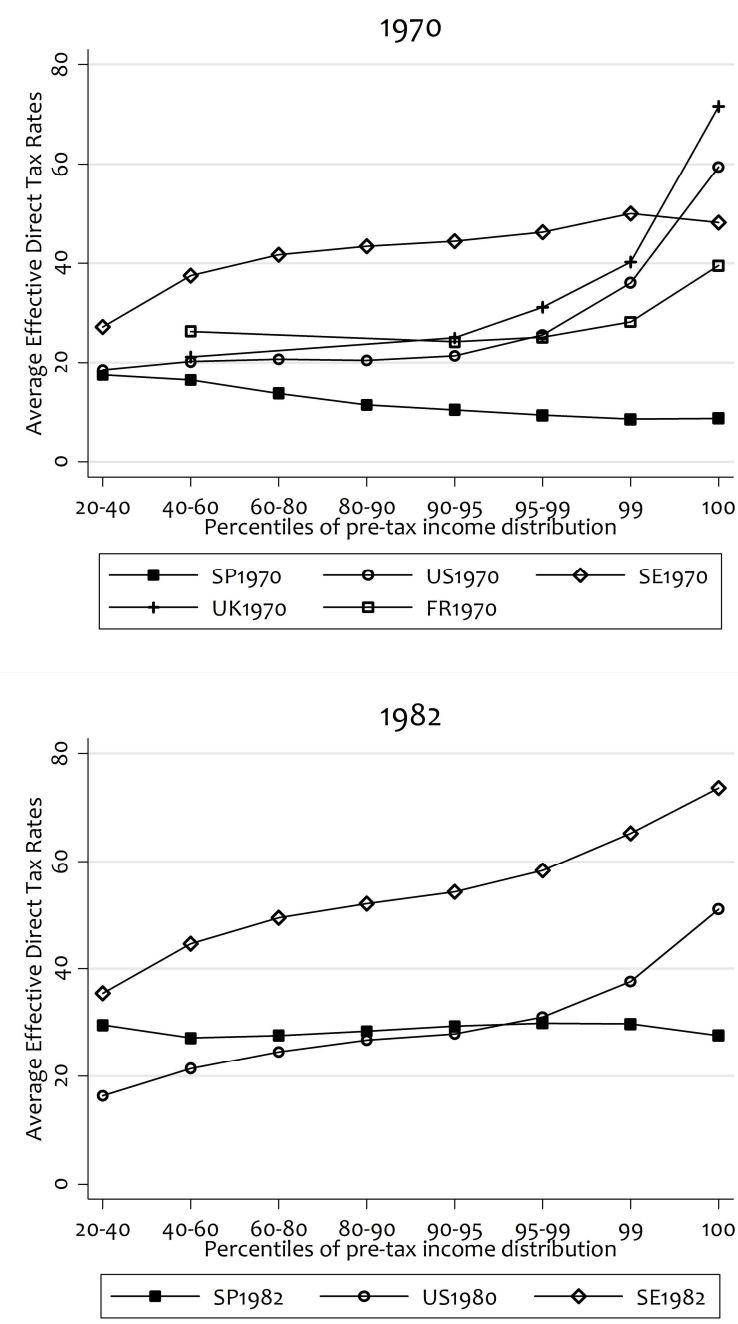

27 The Spanish case includes PIT (1970: taxes on labour and capital income), social contributions, and taxes on corporations, inheritance and wealth. Corporate taxation is not considered in the calculations for France, UK and Sweden. The AETRs for Spain shown in the figure are different from my baseline results because, out of coherence, the weighting unit is the household and pre-tax income excludes imputed rents. 


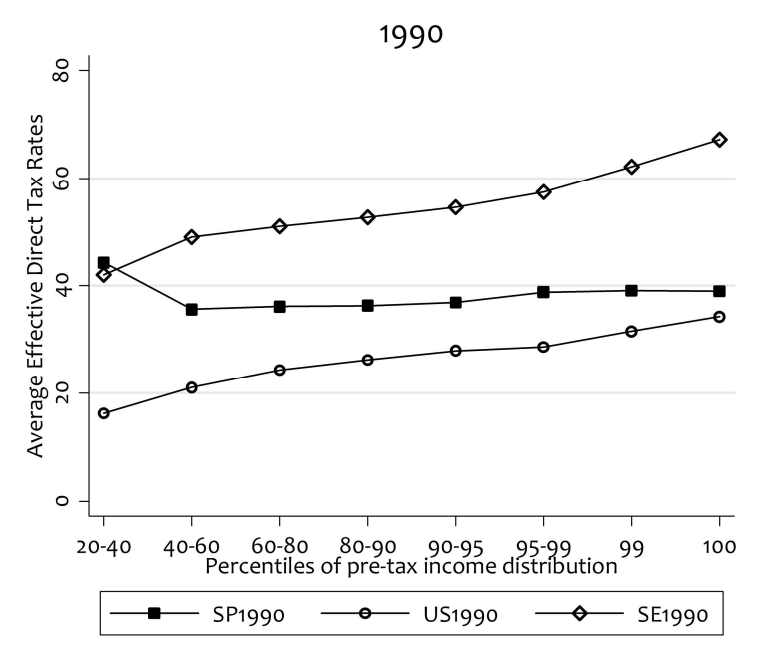

Source: see the online Appendix H.

(1) In the data for France, P40-60 is P0-90.

(2) In the data for France, the US and the UK, the last two values represented are respectively those for P99-99.5 and the mean of rates for P99.5-99.9, P99.9-99.99, and P99.99100. Similarly, for Sweden the first value is $\mathrm{P} 0-40$ and the last two values P99-99.9 and P99.9-100. This means that my top rates refer to relatively lower percentiles, and might therefore be slightly underestimated (overestimated) if there is progression (regression).

What about other nations, and specially those experiencing democratization in similar periods? In figure 5 I attempt a comparison with Portugal, Greece and Italy. The first two underwent resembling political upheavals, while Italy has economic and cultural parallels but has enjoyed unbroken democracy since the mid 20th century. I have also included the mean of EU-11 (other EU-15) and other OECD countries as a benchmark. Regrettably, data on total redistribution is not available, and the exercise is limited to direct taxes plus public benefits. ${ }^{28}$

The graph shows the historical estimations for Spain together with more recent ones for the rest of the countries. Our trend seems consistent with the situation in the other Southern European countries at the end of the nineties, and their levels appear near to those of the EU-11 core - but a significant differential remained if we look at relative redistribution (equalization of incomes with respect to the need for it). The data, however, need to be interpreted with caution. Immervoll et al. (2007), the source for European countries, use a simulation procedure which does not account for the revenue effect of tax evasion: given that this problem more acute in the South, redistribution in this area is likely overestimated with respect to the EU-11.

28 The comparison is thus affected by the relative weight of indirect taxation, which according to OECD data has historically been higher in Portugal and Greece. 
Figure 5: Redistribution by Direct Taxes and Transfers

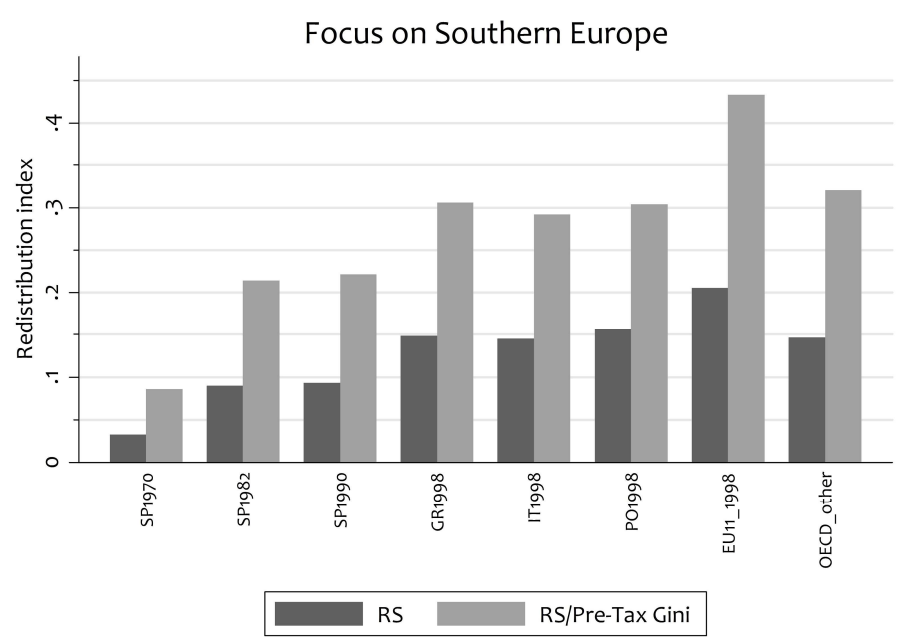

Source: see the online Appendix H.

Abbreviations: SP (Spain), GR (Greece), IT (Italy), PO (Portugal). "Other OECD": Australia, Canada, Czech Republic, Estonia, Iceland, South Korea, Norway, Poland, Slovenia, Slovakia and the US; mostly for the year 2004.

Interestingly, Italy does not appear different from the other, in spite of its long standing democracy. In fact, during the seventies the country underwent tax reforms with similar spirit than the Spanish ones, related to the construction of the common market in the $\mathrm{EEC} / \mathrm{EU}$.

In figure 6 I deal with total monetary redistribution (i.e., now considering also indirect taxes). Again it can be seen that Spain in 1970-90 stands clearly behind the UK or the US in the same years. Convergence with these countries (small, liberal welfare states) was not attained throughout the period of analysis. Regrettably, I have not found such data for other cases in Europe. ${ }^{29}$

With Latin America, similarities are stronger. Today's Chile or Uruguay display levels of redistribution quite close to the Spanish ones in 1990. There has been a recent trend towards increasing redistribution in this region (Lustig, 2011), a process comparable to the Spanish reform studied here. A new "fiscal pact" is sought to contribute to a more equitable society, after the eighties witnessed the introduction of VAT and the flattening of income tax schedules. These early changes contributed to strengthen the tax administration, which may be a positive legacy (Bird and Zolt, 2013). The order is contrary to that of Spain, where direct taxation was reformed first, following the economic thought of the sixties, and to a certain extent lacked the capacity to be enforced.

29 The comparison with the US is not completely accurate, since general sales taxes collected by the states are not included. Those have nevertheless lower rates than VAT, generally well under $10 \%$. It should also be mentioned that in-kind transfers might change the conclusion; see Garfinkel et al. (2006). 
Figure 6: Redistribution in Tax-Benefit systems
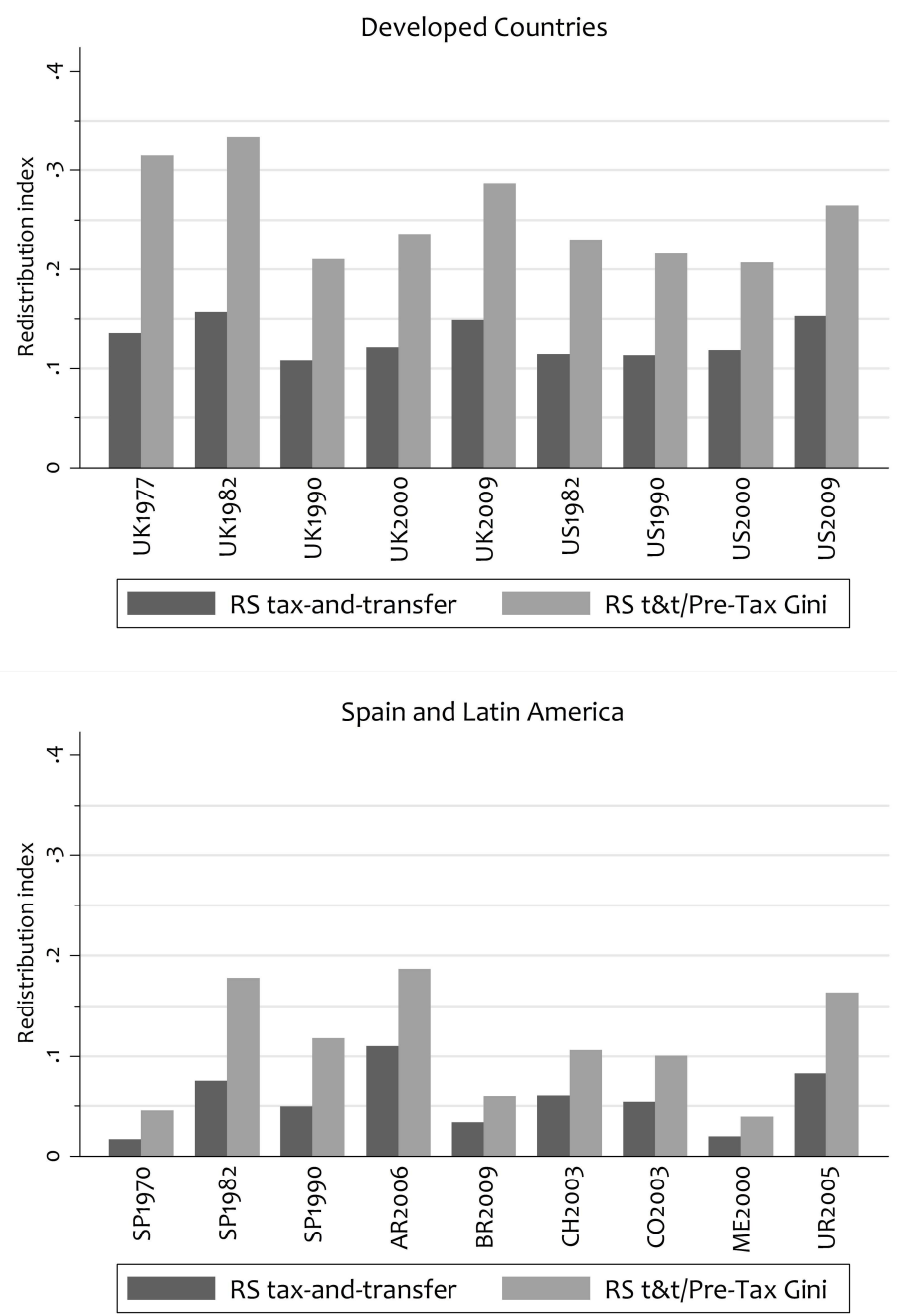

Source: see the online Appendix H.

Abbreviations: SP (Spain), AR (Argentina), BR (Brazil), CH (Chile), CO (Colombia), ME (Mexico), UR (Uruguay), UK (United Kingdom), US (United States of America).

\section{Conclusions}

During the years under study, fundamental political changes took place in Spain. After forty years, dictatorship reluctantly gave way to parliamentarism. At the same time, a tax reform was initiated, promising to bring the country closer to its European neighbours and towards progressivity. But how big a change did it entail in terms of tax burden distribution? Was convergence reached? Did the political transition have a fiscal counterpart?

I have shown that the tax system was regressive in 1970, and still so twenty years later, albeit a lot less. The evolution was thanks to the reforms in direct taxation (fundamentally PIT) and social contributions (which nevertheless remained regressive), while indirect taxation had an increasingly negative impact, given changes in the underlying distribution 
of consumption. The lack of overall tax progressivity contradicts the predominant political discourse about the objectives and effects of the tax reform. ${ }^{30}$

The tax system exacerbated income inequality: it effected inverse redistribution. Moreover, this unequalising impact grew bigger over time, due to the increase in average tax rates (the expansion of public revenues is one of the most important features of the period: it increased from $18 \%$ in 1970 to $33 \%$ in 1990). ${ }^{31}$ Both pre-tax and post-tax incomes grew more unequal. Disposable income inequality, however, was quite constant, and post-tax-and-transfer income remained significantly less concentrated. This means that private and, especially, public transfers counteracted the growth in market inequality and the increasingly negative effect of taxation. The study of public expenditure reveals itself as an essential complement.

The Spanish experience is thus an example of a "third wave" democratization that was followed by a very significant tax reform, which nevertheless failed to radically alter the distribution of the burden. As a result, inequality was not effectively reduced, challenging again the classic Meltzer and Richard (1981) model. There was no 'fiscal revolution': the path was hindered by changes in the political and economic environment. Similar situations might be found in other late-democratising Southern European countries - but also, significantly, in Italy. Other aspects for further research arise. As has been explained, these calculations do not account for the distributive impact of tax evasion, which is expected to erode progressivity: therefore, the introduction of this aspect would reinforce the results obtained here, which could be read as an upper bound. Moreover, the explanation of the findings in a political economy framework, with a comparative perspective, is still required. An in-depth study of attitudes towards taxation and redistribution, and of their transmission to public policies, should follow - helping us understand why Spain did not reach convergence with its more developed neighbours, and continued to fund its public sector with regressive taxation.

\section{References}

ACEMOGLU, D., S. NAIDU, P. RESTREPO, and J. A. ROBINSON (2013). Democracy, Redistribution and Inequality. NBER Working Papers 19746.

ACEMOGLU, D. and J. A. ROBINSON (2001). A Theory of Political Transitions. American Economic Review 91(4), 938-963.

AIDT, T. S. and P. S. JENSEN (2009). The taxman tools up: An event history study of the introduction of the personal income tax. Journal of Public Economics 93(1-2), 160175.

ALBERTUS, M. and V. MENALDO (2014). Gaming democracy: Elite dominance during transition and the prospects for redistribution. British Journal of Political Science 44, 575-603.

ALESINA, A. and D. RODRIK (1994). Distributive politics and economic growth. Quarterly Journal of Economics 109(2), 465-490.

\footnotetext{
30 To be found in official documentation, such as the Moncloa Pacts or the Spanish Constitution (art. 31), but also e.g. in press testimonies: according to F. Fernández Ordóñez, minister of Public Finance between 1977 and 1979, the reform was quite successful at its goal of "paying better; that is, in a fair way, following the old principle and desire that those who have more pay more. [...] Tax progressivity has been extended completely to all revenues, whichever their origin and size, radically altering the pre-existing situation” (Fco. Fernández Ordóñez: “La reforma fiscal, ¿un ademán solitario?”, El País, 18th June 1980).

${ }^{31}$ GDP from Prados de la Escosura (2003).
} 
ALVIRA, F. and J. GARCÍA (2005). Los límites de los efectos redistributivos de la política tributaria. In J. Ruiz-Huerta (Ed.), Políticas Públicas y distribución de la renta, pp. 757-796. Bilbao: Fundación BBVA.

ARGIMÓN, I., J. M. GONZÁLEZ-PÁRAMO, and R. SALAS (1987). ¿Quién pagaba los impuestos indirectos en España? Un ejercicio de reparto de la carga impositiva indirecta en 1980. Hacienda Pública Española 104, 99-127.

BANDRÉS, E. (1993). La eficacia redistributiva de los gastos sociales. Una aplicación al caso español (1980-1990). In I Simposio sobre Igualdad y Distribución de la Renta y Riqueza, Volume VII, Sector Público y Redistribución, pp. 123-172. Madrid: Fundación Argentaria.

BANDRÉS, E. and A. CUENCA (1996). Análisis y evaluación del contenido redistributivo de las pensiones públicas en España. In II Simposio sobre Igualdad y Distribución de la Renta y la Riqueza, Volume VII. Madrid: Fundación Argentaria.

BARNARD, A., S. HOWELL, and R. SMITH (2011). The effects of taxes and benefits on household income, 2009/10. Further analysis and methodology, Office for National Statistics, UK.

BATES, R. H. and D.-H. D. LIEN (1985). A note on taxation, development, and representative democracy. Politics and Society 14, 53-70.

BENGTSSON, N., B. HOLMLUND, and D. WALDENSTRÖM (2012). Lifetime versus Annual Tax Progressivity: Sweden, 1968-2009. Working Paper Series 2012:13, Center for Labor Studies, Uppsala University.

BIRD, R. and E. ZOLT (2013). Taxation and Inequality in the Americas: Changing the Fiscal Contract? Working Paper 13-15, International Center for Public Policy.

BOIX, C. (2003). Democracy and redistribution. Cambridge: Cambridge University Press.

BRECEDA, K., J. RIGOLINI, and J. SAAVEDRA (2009). Latin America and the Social Contract: Patterns of Social Spending and Taxation. Population and Development Review 35(4), 721-748.

CALERO, J. (2001). La incidencia distributiva del gasto público social. Análisis general y tratamiento específico de la incidencia distributiva entre grupos sociales y entre grupos de edad. Papeles de Trabajo 20/01, Instituto de Estudios Fiscales.

CALVO SOTELO, L. (1990). Memoria viva de la transición. Esplugues de Llobregat (Barcelona): Plaza y Janés.

COMÍN, F. (2007). Reaching a Political Consensus for Tax Reform in Spain: The Moncloa Pacts, Joining the European Union and the Rest of the Journey. In J. Martínez Vázquez and J. F. Sanz Sanz (Eds.), Fiscal Reform in Spain. Accomplishments and Challenges, pp. 8-57. Cheltenham, UK: Edward Elgar.

COMÍN, F. (2010a). Los seguros sociales y el Estado del Bienestar en el siglo XX. In J. P. y J. Silvestre (Ed.), Los orígenes del Estado del Bienestar en España, 1900-1945: los seguros de accidentes, vejez, desempleo y enfermedad, pp. 17-49. Zaragoza: Prensas Universitarias de Zaragoza.

COMÍN, F. (2010b). Public Finance and the Rise of the Liberal State in Spain, 1808-1914. In J. Cardoso and P. Lains (Eds.), Paying for the Liberal State. The Rise of the Public Finance in Nineteenth-Century Europe, pp. 214-250. Cambridge: Cambridge University Press. 
COMÍN, F. and M. MARTORELL (2013). La Hacienda Pública en el franquismo. La guerra y la autarquía (1936-1959). Madrid: Instituto de Estudios Fiscales.

COMÍN, F., J. PAN-MONTOJO, J. PRO, R. VALLEJO, and J. ZAFRA (1995). La práctica fiscal en la España contemporánea. Una historia de la Administración tributaria (1800-1990). Memoria al Instituto de Estudios Fiscales. Madrid.

DOMÍNGUEZ, F., J. LÓPEZ, and F. RODRIGO (2013). El hueco que deja el diablo: una estimación del fraude en el IRPF con microdatos tributarios. WP FUNCAS 728, 1-34.

DURÁN, J. and A. ESTELLER (2010). La imposición sobre la riqueza: ¿una forma de gravamen en caída libre? Revista de Economía 4, 71-79.

FREEMAN, J. and D. QUINN (2012). The economic origins of democracy reconsidered. American Political Science Review 106, 58-80.

FUENTES QUINTANA, E. (2004). Los Pactos de la Moncloa y la Constitución de 1978. In E. Fuentes Quintana (Ed.), Economía y economistas españoles, Volume 8, pp. 163238. Barcelona: Galaxia Gutenberg: Círculo de Lectores.

FULLERTON, D. and G. E. METCALF (2002). Tax Incidence. Handbooks in Economics, vol. 4. Amsterdam; London and New York: Elsevier Science, North-Holland.

GARFINKEL, I., L. RAINWATER, and T. M. SMEEDING (2006). A re-examination of welfare states and inequality in rich nations: How in-kind transfers and indirect taxes change the story. Journal of Policy Analysis and Management 25(4), 897-919.

IMMERVOLL， H., H. LEVY， C. LIETZ, D. MANTOVANI, C. O'DONOGUE, H. SUTHERLAND, and G. VERBIST (2007). Household Incomes and Redistribution in the European Union: Quantifying the Equalising Properties of Taxes and Benefits. Working Paper 48, European Network of Economic Policy Research Institutes.

INSTITUTO DE ESTUDIOS FISCALES (1973). Informe sobre el sistema tributario español (2002 ed.). Madrid: IEF.

LINDERT, P. (1994). The Rise of Social Spending, 1880-1930. Explorations in Economic History 31(1), 1-37.

LINDERT, P. (2004). Growing Public. New York: Cambridge University Press.

LUSTIG, N. (2011). Fiscal policy and income redistribution in Latin America: challenging the conventional wisdom. Working Paper 227, ECINEQ, Society for the Study of Economic Inequality.

MANRESA, A. and S. CALONGE (2001). La incidencia impositiva y la redistribución de la renta en España: un análisis empírico. Papeles de Economía Española 88, 216-229.

MELTZER, A. and S. RICHARD (1981). A Rational Theory of the Size of Government. Journal of Political Economy 89, 914-927.

MILANOVIC, B. (2000). The median voter hypothesis, income inequality, and income redistribution: an empirical test with the required data. European Journal of Political Economy 16(3), 367-410.

MULLIGAN, C. B., R. GIL, and X. SALA-I-MARTIN (2004). Do Democracies Have Different Public Policies than Nondemocracies? Journal of Economic Perspectives 18(1), $51-74$.

ONRUBIA, J., F. PICOS-SÁNCHEZ, and M. C. RODADO (2014). Rethinking the Pfähler-Lambert decomposition to analyse real-world personal income taxes. International Tax and Public Finance 21(4), 796-812. 
ONRUBIA, J., M. C. RODADO, S. DÍAZ, and C. PÉREZ (2007). Progresividad y redistribución a través del IRPF español: Un análisis de bienestar social para el periodo 1982-1998. Hacienda Pública Española 183, 81-124.

ONRUBIA, J., R. SALAS, and J. SANZ (2005). Redistribution and labour supply. Journal of Economic Inequality 3(2), 109-124.

PAN-MONTOJO, J. L. (1996). Una larga e inconclusa transición: la reforma tributaria, 1977-1986. In J. Tusell and A. Soto (Eds.), Historia de la transición. 1975-1986, pp. 264304. Madrid: Alianza.

PEICHL, A. and P. VAN KERM (2007). Progres: Module to measure distributive effects of an income tax. Statistical Software Components S456867, Boston College Department of Economics.

PERONA, D. (1972). La distribución de la carga tributaria en España. Madrid: Instituto de Estudios Fiscales.

PERSSON, T. and G. TABELLINI (1994). Is Inequality Harmful for Growth? American Economic Review 84(3), 600-621.

PIKETTY, T. and E. SAEZ (2007). How Progressive Is the U.S. Federal Tax System? A Historical and International Perspective. Journal of Economic Perspectives 21(1), 3-24.

PRADOS DE LA ESCOSURA, L. (2003). El progreso económico de España (18502000). Bilbao: Fundación BBVA.

SCHEVE, K. and D. STASAVAGE (2012). Democracy, War, and Wealth: Lessons from Two Centuries of Inheritance Taxation. American Political Science Review 106(1), 81102.

SCHUMPETER, J. (1954). The Crisis of the Tax State. International Economic Papers 4, 5-38.

STEINMO, S. (1989). Political Institutions and Tax Policy in the United States, Sweden, and Britain. World Politics 41, 500-535.

TIMMONS, J. (2005). The Fiscal Contract: States, Taxes, and Public Services. World Politics 57, 530-576.

TORREGROSA, S. (2014a). Evasion and Progressivity in the Spanish income tax (19702001). Paper presented at UC Davis Economic History seminar.

TORREGROSA, S. (2014b). Sticky income inequality in the Spanish transition (19731990). UB Economics Working Papers E14/319.

WANG, C. and K. CAMINADA (2011). Disentangling Income Inequality and the Redistributive Effect of Social Transfers and Taxes in 36 LIS Countries. MPRA Paper 32821. 


\section{Appendices}

\section{A Tax revenue series}

The tax data I use are on a accrual basis (i.e. not budgeted figures, nor cash flows either). In some cases, they have been obtained from those other budgetary phases which precede or follow, applying the corresponding adjusting factor. ${ }^{32}$

The existence of regional tax autonomy in some regions has made several adjustments necessary. During the dictatorship, the provinces of Álava and Navarra had distinct taxing power on most items (generally, with high regulatory capacity in the direct ones and only collection management in the indirect ones). Of these they kept a part for themselves and transferred an annual payment to the State (cupo) as their share in the common budget. This means (apart from other aspects $)^{33}$ that the revenue of e.g. land taxes in these provinces is not included in the general figure, so I had to disaggregate them from the corresponding provincial administrations' revenue to integrate them in the study. This has been done resorting to budgeted data or applying the general national structure: I am therefore not considering the difference that might exist in the tax burden distribution with respect to the rest of the nation. ${ }^{34}$ For the post-transition period, a very similar regime persists in the Autonomous Communities of Navarra and País Vasco (which includes not only Álava but also its neighbouring provinces Guipúzcoa and Vizcaya). Information on revenues is also not totally integrated, but improved enough for the purpose of this analysis (the central statistics do show now how much, say, income tax was raised in these areas).

On the contrary, the Canary Islands and the cities of Ceuta and Melilla have been excluded from the computations because of their specific regime in indirect taxation. It is considered that their presence would bias the results (since there is lighter indirect burden, it would mean to underestimate the regressivity of the general system - not too much, though, because of their small share in national income and tax revenue). So, in the results, 'Spain' refers to the Península and the Balearic Islands.

Table 1 shows the tax revenue data used in the study. The series have been obtained from official sources: totals are from Cuentas de las Administraciones Públicas, which provide information for the whole of the General Government and its different components, while higher detail on the Central State's numbers comes from Cuenta General del Estado - Cuenta de la Administración General del Estado. These have been consulted in the Archives of the Public Finance Ministry and the IGAE (Intervención General de la Administración del Estado). Several publications of the Ministry of Public Finance have been used for other purposes: information on the taxes of autonomous communities ("impuestos concertados") has been obtained from Recaudación y estadísticas de la reforma tributaria, while disaggregation of municipal taxes comes from Liquidación de presupuestos de las CCLL. Some further disaggregation, not shown in the table but used in the calculations, comes from archival sources (direct taxes) or other publications (indirect taxes details by groups of goods): Información Estadística del Ministerio de Hacienda (1960-72) and Estadisticas Presupuestarias y Fiscales (1973-89).

\footnotetext{
32 It might be conceptually more solid to use cash-flow figures, but the accrual criterion has been chosen because of various reasons; fundamentally the availability of consolidated data for all Public Administrations and the fact that it is the most widely used in international statistics. The difference between both quantities is insignificant in most cases.

${ }^{33}$ The cupo system was legislated upon for long periods of time, specially in the case of Navarra, and fixed in nominal terms. This obviously entailed a progressive reduction in the value of real central revenue coming from these territories, aggravated in times of high inflation (of which there were several episodes during the dictatorship).

${ }^{34}$ And which most likely does exist to a certain extent. In recent times, it is known to mean a lighter burden on corporations, for example.
} 
Table 1: Tax Revenue in the Península and the Balearic Islands

\begin{tabular}{|c|c|c|c|c|c|c|c|}
\hline & 1960 & 1964 & 1970 & 1976 & 1982 & 1985 & 1990 \\
\hline Land Tax / Real Estate Tax & 3.142 & 3.859 & 6.297 & 17.421 & 57.873 & 74.745 & 275.955 \\
\hline Payroll Tax & 5.273 & 8.287 & 21.393 & 124.174 & - & - & \\
\hline Capital Income Tax & 2.541 & 3.642 & 8.823 & 48.277 & - & - & \\
\hline Industrial Tax: Fiscal License & 1.165 & 2.765 & 4.330 & 9.506 & - & - & \\
\hline Industrial Tax: Profits Tax & 1.404 & 2.476 & 6.694 & 16.443 & - & - & \\
\hline Inheritance Tax & 1.438 & 2.199 & 4.163 & 10.911 & 27.077 & 37.372 & 81.005 \\
\hline Corporation Tax (1) & 7.497 & 10.249 & 28.948 & 80.584 & 256.750 & 440.855 & 1.567 .274 \\
\hline Personal Income Tax (2) & 1.131 & 1.813 & 3.384 & 10.408 & 962.819 & 1.584 .948 & 3.756 .698 \\
\hline Local Land taxes & 574 & 1.174 & 3.794 & 10.463 & 33.398 & 56.394 & 84.721 \\
\hline Wealth Tax & - & - & - & - & 19.166 & 25.939 & 94.291 \\
\hline Local Fiscal License & - & - & - & - & 62.640 & 83.095 & 156.259 \\
\hline Local Vehicles Tax (3) & - & - & - & - & - & - & 94.028 \\
\hline Other & 6.010 & 9.464 & 8.946 & 27.223 & 32.134 & 86.523 & 15.974 \\
\hline DIRECT TAXES & 30.175 & 45.929 & 96.773 & 355.409 & 1.451 .858 & 2.389 .871 & 6.126 .204 \\
\hline Stamp Duties & 8.706 & 14.879 & 23.639 & 72.927 & 146.440 & 189.125 & $\overline{480.130}$ \\
\hline Tariffs & 6.855 & 20.003 & 40.939 & 92.640 & 228.303 & 360.576 & 336.111 \\
\hline Oil Monopoly & 2.908 & 6.070 & 13.798 & 31.169 & 0 & 0 & 90.887 \\
\hline Tobacco Monopoly & 2.320 & 3.441 & 7.063 & 11.435 & 26.221 & 27.305 & \\
\hline Luxury Tax & 6.425 & 13.439 & 37.996 & 103.356 & 195.477 & 297.472 & - \\
\hline ture Tax / Excises & 13.317 & 16.709 & 21.396 & 29.925 & 240.203 & 441.955 & 970.140 \\
\hline Sales Tax (IGTE) & - & 2.496 & 31.732 & 62.377 & 317.427 & 694.346 & 19.914 \\
\hline Local Vehicles Tax (3) & - & - & - & - & 18.995 & 41.391 & \\
\hline Value Added Tax & - & - & - & - & - & & 2.774 .119 \\
\hline Other & 3.439 & 4.093 & 4.215 & 22.265 & 148.413 & 266.353 & 61.385 \\
\hline INDIRECT TAXES & 43.971 & 81.130 & 180.779 & 426.093 & 1.321 .479 & 2.318 .523 & 4.731 .538 \\
\hline Public Employees & 241 & 269 & 2.155 & 4.375 & 15.836 & 29.220 & 59.343 \\
\hline Employers' & 16.093 & 31.356 & 128.362 & 504.113 & 1.728 .908 & 2.299 .311 & 4.264 .645 \\
\hline Employees & 5.035 & 10.907 & 25.410 & 85.941 & 336.082 & 519.801 & 905.996 \\
\hline Self-Employed & - & - & 4.389 & 21.552 & 131.884 & 231.226 & 402.840 \\
\hline Unemployed & - & - & 1.186 & 12.669 & 104.980 & 175.900 & 302.071 \\
\hline SOCIAL CONTRIBUTIONS & 21.369 & 42.532 & 161.502 & 628.649 & 2.317 .690 & 3.255 .458 & 5.934 .895 \\
\hline TOTAL TAXES & 95.515 & 169.591 & 439.053 & 1.410 .152 & 5.091 .027 & 7.963 .852 & 16.792 .636 \\
\hline
\end{tabular}

All taxes in nominal million pesetas.

Source: Author's calculations, based on official publications and archival documentation, mainly Cuentas de las Administraciones Públicas and Cuenta General del Estado.

(1) Corporate Income Tax includes a tax on equity issuance in 1970 and 1976.

(2) Personal Income Tax includes its precedents Contribución General sobre la Renta (1960 and 1964) and I. General sobre la Renta de las Personas Físicas (1970 and 1976), although they were of a different nature (super-tax on high incomes).

(3) The vehicles tax is classified in local budgets as indirect until 1989 and since then as direct.

The social contributions totals are from Cuentas de las Administraciones Públicas, adding those from public employees (which appear as a direct tax in the Central Government statistics) and disaggregating several components: the contributions of the self-employed (1967-79, taken from National Accounts, Contabilidad Nacional de España), of the unemployed (1967-79 from Memoria Estadística de las Contingencias de la Seguridad Social Administradas por el INP, 1980-84 from Anuario de Estadisticas Laborales of the Labour and Social Security Ministry), and the agrarian special regime (1981-90, Anuario de Estadisticas Laborales, 1970 from Memoria Estadística de los Seguros Sociales administrados por el INP.) There is a discontinuity in the social contributions series in 1967 (when the social security law came into force), which I have not been able to eliminate. It is related to the introduction of family protection in the aggregate accounting (the explanation can be found in Instituto Nacional de Estadística, 1968). 


\section{B Methodological discussion}

\section{B.1 Annual analysis versus alternatives}

This paper takes an annual approach, as is usual in most of the literature. There are, however, other options, suggested by several scholars to tackle the variability of income across the life cycle: using yearly taxes on "permanent income" or applying a lifetime perspective.

In the first case, permanent income is normally obtained with an econometric estimation or proxied by the level of current consumption (Poterba, 1989). Such an approach would be valid in the presence of perfect capital markets; nonetheless, taking this as a baseline assumption seems rather unrealistic to the author.

The lifetime-income-lifetime-burden perspective is conceptually different. It attempts to calculate the total amount earned and paid in taxes by an individual throughout her life (Davies et al., 1984; Fullerton and Rogers, 1993). Given the inconsistency of tax policy in such a long term, this exercise reflects only a hypothetical scenario. However, if it is thoroughly undertaken, the lifetime analysis would allow disentangling interpersonal from inter-temporal redistribution: its results would correspond only to the first one (Bengtsson et al., 2012). ${ }^{35}$ Nonetheless, income smoothing is also an important dimension in the Welfare State, taken into account in the present research with the annual calculations. This framework is also less demanding in terms of data (a hard constraint in our case) and more consistent in a context of changing tax policy.

It should also be noted that this paper does not consider any dynamics: when discussing the effects of the tax system on income inequality, it is always inside the annual benchmark, between different "phases" of income defined in the main text. I am not trying to assess the effects of taxation in one year on inequality in subsequent years.

\section{B.2 Incidence hypotheses}

Social contributions have been the centre of important debate in the country, specially in relation to the causes of unemployment. The question whether employers' contributions are borne by them or by the worker (via a smaller net salary) remains unsolved. International literature concludes that workers would eventually assume the whole burden (Gruber and Krueger, 1991; Gruber, 1997), but studies with Spanish data show no consensus. Most cited is Argimón and GonzálezPáramo (1987), which states a 100\% impact on workers; however, others have reached different results: for Toharia (1981) there would be shifting to prices, Escobedo (1991) found incidence on salaries around $40 \%$ and finally Melguizo (2007) concluded that the cost was borne by enterprises.

The institutional framework in which Social Security was introduced in the country, together with evidence on the scarce initial resistance of employers to the contributions (Molinero and Ysàs, 1998) point towards incidence on workers. According to theory, this would be the result with rigid labour supply, which is close to the findings of international and national empirical work (Blundell and Macurdy, 1999; Fernández Val, 2003). I therefore use this as the baseline hypothesis, but in combination with a mixed alternative, since several studies point at social contributions among the causes of high unemployment in the country (something that would not be the case if they were completely paid by workers). The political and institutional change might have favoured a decrease in shifting, given that workers' bargaining power grew with the legalization of labour unions. Towards the end of the 1970s businesses started to make noisier complaints about the burden of social contributions (Cabrera and Del Rey, 2002). The alternative hypothesis imputes $50 \%$ of the tax to employees, $25 \%$ to the employer and $25 \%$ to consumers (these calculations are available in Appendix F.2). ${ }^{36}$

\footnotetext{
${ }^{35}$ I am referring to inter-temporal "life-cycle" redistribution, not between generations.

${ }^{36}$ The same incidence hypotheses are applied to both workers' and employers' social contributions. Although studies have always considered the first paid by workers, it is inconsistent with incidence theory to make a distinction.
} 
Concerning the Corporation tax, there is barely any empirical evidence for Spain: only a study from the seventies that concluded shifting to prices, related to oligopolization (Lagares, 1976). The conventional assumption is that in an economy with fixed capital supply, this factor will bear the burden, while a portion would pass on to labour if that condition is relaxed (effects on savings or international capital mobility). The openness of the Spanish economy was increasing during our period of study, but departing from a very low level; it could therefore be considered plausible that shifting towards labour was weak. The lack of solid evidence, however, makes me turn to a balanced incidence between the three possible bearers of the tax (Appendix F.3 includes alternative estimations).

There has also been discussion in the case of Real Estate taxes. They can be considered a tax on housing services, borne by the tenant in rented properties; it has also been maintained that a part of the tax could be falling on the owners and potentially shifted to other forms of capital (Mieszkowski, 1972). Applied literature has mostly imputed it on occupiers, be them owners or tenants. Nevertheless, the rigid regulation of the Spanish housing market since the 1920s (freeze on rental prices until liberalization in 1985), leads me to consider an alternative estimation with $50 \%$ of the tax paid by owners (see Appendix F.4).

\section{B.3 Equivalization of incomes and weighting}

Following the standards in welfare literature, all income data are equivalized before calculating inequality indices. An equivalence scale is a transformation of household incomes to obtain an adjusted "per capita" value that takes into account economies of scale within the family (and assumes that all members share their income equally).

I use the OECD scale, which gives value 1 to the first adult, 0.7 to the subsequent ones and 0.5 to minors (up to 14 years old). This choice is consistent with empirical results based on Spanish data (Bosch-Domenech, 1991; Duclos and Mercader-Prats, 1999; Labeaga et al., 2004).

Households are then weighted by their real size. This implies that the results are given in terms of individuals, not households: attributing the same importance to all persons regardless of the family they belong to.

\section{Detailed imputation methodology}

The estimation of tax payments consists in allocating the revenue of each tax using the distribution of the corresponding tax base across households:

$$
T_{h, t}=\frac{B_{h, t}}{\sum_{h=1}^{n} B_{h, t}} \sum_{h=1}^{n} T_{h, t}
$$

where $T_{h, t}$ is the estimated amount of tax $t$ paid by household $h, B_{h, t}$ the corresponding tax base, and $n$ the number of households. This formula has been applied generally, for taxes that are proportional to the base, at the highest possible level of disaggregation (e.g., excises on specific goods or differential rates in VAT). Some items, however, required different calculations, for example the inheritance tax and PIT (which are progressive and for which we have better data).

\section{C.1 Social contributions}

The data permit distinguishing those paid by workers, employers, self-employed workers, and the unemployed (on their behalf by the unemployment insurance). For the first two groups, the General Regime and the Special Regime for Agrarian Workers have been considered separately.

\section{Worker's contributions}

The tax base (Bases de Cotización) has been simulated with the information on salaries and wages in the HBSs.

1. Correspondence between socio-professional category in the Social Security regulations and socio-economic category and education level in HBSs. In 1970 and 1982, each household 
has been assigned the category of the household head; the 1990 data allow inferring the category of each working household member.

2. In 1970 there was one Base Tarifada for each category. For the following years, the tax base is either the minimum or maximum threshold established by the regulations, or the salary if it lies between the two. Household tax base is the sum of the individual tax bases.

3. Further adjustments and approximations have been made when we lack information on the salary, employment periods or working hours of each member.

\section{Employer's contributions}

The part falling on the employer is distributed according to entrepreneurial income of "empresarios con asalariados" (entrepreneurs with salaried workers) and capital incomes (to capture the impact of employees of corporations and incidental shifting).

\section{Contributions of the self-employed}

According to the distribution of entrepreneurial income of the corresponding socio-economic categories in the HBSs.

\section{Contributions of the unemployed}

Distributed according to unemployment benefits in 1990. In previous years, using the distribution of transfers (there is no disaggregation available) when there is unemployment in the household having worked previously (in 1982 we have information on each member, in 1970 only of the household head).

\section{C.2 Direct taxes}

Almost every tax has a component paid directly by households and another that falls first on enterprises and only gets to the final taxpayer through profits and prices. This second component has always been distributed with the criterion used for the Corporation tax. ${ }^{37}$

\section{Urban Land Tax (Contribución Territorial Urbana - Impuesto de Bienes Inmuebles)}

In proportion to housing expenditure (real or imputed rent). The HBSs of 1982 and 1990 have some data on the tax paid by owner-occupiers, which is assumed to be $80 \%$ of the total revenue (given the distribution of housing regimes in 1990). The remaining $20 \%$ has been distributed according to rents paid, also for the owner-occupiers not reporting their tax.

\section{Rural Land Tax (Contribución Territorial Rústica)}

Distributed according to entrepreneurial incomes of agricultural land proprietors (socio-economic categories in HBSs). I have distinguished between the fixed and the variable part of the tax.

\section{Industrial Tax (Impuesto Industrial)}

Distributed according to entrepreneurial incomes of urban entrepreneurs (socio-economic categories in HBSs). I have distinguished between the fixed and the variable part of the tax.

\section{Capital Income Tax (Impuesto sobre las rentas del capital)}

Using the distribution of positive incomes from capital.

\section{Labour Income Tax (Impuesto sobre las rentas del trabajo personal)}

The licence part has been distributed among the socio-economic category of professionals, the variable one using the distribution of income from labour over the threshold (60.000 ptas).

\footnotetext{
$3720 \%$ of land and housing taxes, and, $75 \%$ of the tax on income from capital, $60 \%$ of the fiscal licence, $40 \%$ of municipal land taxes and $30 \%$ of the tax on vehicle circulation.
} 


\section{Municipal Land Tax (I. Terrenos y Solares)}

In proportion to the sum of income from capital and imputed rents.

\section{Corporation Tax (I. Sociedades and I. Especial del 4\%)}

According to the distribution of positive income from capital, total monetary expenditure and income from labour. The central estimation weighs each of these components by a third (alternatives in section F.3).

\section{Old Income Super-tax (I. General Renta Personas Físicas)}

Simulated according to the regulations (tax base, exemption threshold, family and labour allowances, formula, tax credits for product taxes). The resulting quantity is a lot higher the real tax paid, and so is also the number of taxpayers. This is of course evidence of fraud, but out of lack of information to deal with it correctly all the quotas were adjusted proportionally.

\section{Property Tax (I. Patrimonio)}

Property is approximated with a $3 \%$ capitalization of capital incomes, including imputed rents and half the revenues from entrepreneurial labour. The households with higher property have been selected up to the number of taxpayers from the tax statistics (Memoria de la Administration Tributaria), and the actual revenue has been distributed among them using the tax shares paid by each tax base group.

\section{Inheritance Tax (I. Sucesiones)}

I follow here the Office for Tax Analysis of the U.S. Treasury (Cronin, 1999): each potential taxpayer is assigned the product of...

- The resulting quota in case of death (simulated property times the statutory tax rate) ${ }^{38}$, under the assumption of there being two heirs (since it is to them that the tax would correspond).

- The mortality rate in the 5-year age interval (obtained from INE; for 1970 I have used the rate of the 45 year-olds in 1975, since there is no information on age in the HBS).

The basic assumption of this procedure is that the heirs would be in a similar income level than the decedent.

\section{Personal Income Tax (IRPF)}

The distribution of the tax paid (cuota líquida) is obtained, by permilles of taxpayers ranked by their net incomes, from the micro-data provided by the IEF ("PANEL PURO Y EXTENDIDO IRPF 1982/1998 IEF-AEAT (Declarantes)" ). It is then imputed to the corresponding permilles in the HBSs (previously selected from the households, using the information on age and income of each member).

The obtained distribution is applied to the actual tax paid in the year. Total tax payment of the household is calculated as the sum of the quotas of all members.

\section{Vehicles Tax (I. Circulación - I. sobre Vehículos de Tracción Mecánica)}

There are reported payments in the 1990 HBSs, but these do not cover the total quantity: the rest has been simulated using the information on expenditure in gasoline, and the same procedure has been applied in 1982 .

\footnotetext{
38 The formula distinguishes by family closeness, but I have only used the formula for the closest ones, to which the immense majority of inheritors belonged.
} 


\section{C.3 Indirect taxes}

\section{Taxes on specific consumption goods}

Distributed according to the corresponding expenditure items, generally at the 3-digit level of disaggregation in the PROCOME classification (but 4-digit codes were used in some cases). ${ }^{39}$ Thus I imputed taxes on the consumption of tobacco, alcohol, goods subjected to the luxury tax (cars, jewellery, electrical appliances...), and so on.

A part of the revenue of the Oil monopoly and the Hydrocarbons excise is distributed according to total consumption, since it would impact on the production process and final prices.

\section{General consumption taxes}

The General Sales Tax, Stamp duties and transaction tax, and Tariffs have been distributed according to total monetary expenditure (alternatives are explored in section

F.1).

For VAT I have distinguished the groups of goods affected by each rate in 1990 (reduced, general and incremented). The distribution of the tax revenue among these is given in the online database Badespe (Base de Datos Económicos del Sector Público Español, Instituto de Estudios Fiscales). The reduced rate is applied to food, public transport, the editorial sector, medicines, school materials, the hospitality sector, spectacles and housing investment. The incremented rate corresponds to the purchase of cars, jewellery, boats, and so on.

${ }^{39}$ PROCOME is a Eurostat system of classification of consumer goods that was used in HBSs by all EU countries. Further information can be found at Instituto Nacional de Estadística (1992). 


\section{Average Effective Tax Rates by tax}

Here I present AETRs for deciles of individuals (ranked by pre-tax equivalent income), for the main taxes in each year. Generally, I have chosen the ones representing at least $4 \%$ of total tax revenue. IGRPF in 1970 is an exception: it only meant $0.8 \%$ of revenue, and is presented precisely to show its insignificance. In 1982, the Luxury tax represented $3.8 \%$ but I still include it for coherence between the tables. The same reason is behind the inclusion of Tariffs in the last year.

Table 2: Average ETR by deciles, year 1970

\begin{tabular}{lrrrrrrrr} 
& IRTP & IGRPF & ISOC & CSTFE1 & IGTE & LUJO & IIEE & COMEXT \\
\hline Decile 1 & 0.11 & 0.00 & 5.31 & 5.62 & 19.23 & 14.56 & 5.90 & 24.80 \\
Decile 2 & 0.64 & 0.00 & 1.22 & 11.03 & 2.62 & 2.77 & 1.21 & 3.38 \\
Decile 3 & 0.94 & 0.00 & 1.16 & 12.53 & 2.23 & 2.35 & 1.15 & 2.87 \\
Decile 4 & 1.07 & 0.01 & 1.14 & 12.59 & 2.06 & 2.22 & 1.15 & 2.65 \\
Decile 5 & 1.20 & 0.02 & 1.08 & 11.51 & 1.97 & 2.28 & 1.12 & 2.54 \\
Decile 6 & 1.30 & 0.03 & 1.10 & 11.15 & 1.85 & 2.14 & 1.10 & 2.39 \\
Decile 7 & 1.40 & 0.04 & 1.08 & 10.47 & 1.74 & 2.03 & 1.15 & 2.25 \\
Decile 8 & 1.41 & 0.08 & 1.09 & 9.05 & 1.64 & 1.98 & 1.14 & 2.12 \\
Decile 9 & 1.36 & 0.14 & 1.15 & 7.58 & 1.54 & 2.17 & 1.29 & 1.99 \\
Decile 10 & 1.20 & 0.38 & 1.56 & 5.41 & 1.37 & 1.86 & 1.14 & 1.76 \\
\hline \hline Top 5\% & 1.06 & 0.51 & 1.85 & 4.31 & 1.26 & 1.68 & 1.04 & 1.62 \\
Top 1\% & 0.74 & 0.92 & 2.59 & 2.07 & 0.86 & 1.14 & 0.70 & 1.11 \\
\hline \hline
\end{tabular}

Source: Author's calculations.

IRTP (Impuesto sobre los Rendimientos del Trabajo Personal): labour income tax. ISOC (Impuesto de Sociedades): Corporation tax. IGRPF (Impuesto General sobre la Renta de las Personas Físicas): personal income super-tax. CSTFE1: Social Contributions under Hypothesis 1. IGTE (Impuesto General sobre el Tráfico de Empresas): General Sales tax. LUJO: Luxury tax. IIEE (Impuestos Especiales): excises on alcohol, petroleum products, and so on. CEXT: Tariffs and other taxes on international trade. 
Table 3: Average ETR by deciles, year 1982

\begin{tabular}{lrrrrrrr} 
& IRPF & ISOC & CSTFE1 & IGTE & LUJO & IIEE & COMEXT \\
\hline Decile 1 & 0.05 & 9.23 & 5.23 & 33.93 & 10.90 & 7.96 & 24.40 \\
Decile 2 & 1.76 & 1.94 & 13.48 & 5.20 & 2.54 & 2.78 & 3.74 \\
Decile 3 & 3.92 & 1.55 & 14.20 & 3.32 & 1.83 & 2.09 & 2.38 \\
Decile 4 & 4.83 & 1.51 & 15.18 & 2.88 & 1.63 & 2.17 & 2.07 \\
Decile 5 & 5.45 & 1.47 & 15.81 & 2.62 & 1.42 & 1.90 & 1.89 \\
Decile 6 & 5.83 & 1.46 & 16.41 & 2.49 & 1.60 & 1.94 & 1.79 \\
Decile 7 & 6.32 & 1.39 & 16.46 & 2.30 & 1.44 & 1.88 & 1.65 \\
Decile 8 & 6.70 & 1.41 & 16.82 & 2.15 & 1.43 & 1.76 & 1.55 \\
Decile 9 & 7.09 & 1.37 & 17.07 & 1.92 & 1.34 & 1.64 & 1.38 \\
Decile 10 & 9.00 & 1.79 & 14.78 & 1.64 & 1.15 & 1.47 & 1.18 \\
\hline \hline Top 5\% & 10.00 & 2.14 & 12.84 & 1.55 & 1.14 & 1.42 & 1.11 \\
Top 1\% & 12.11 & 3.25 & 8.36 & 1.18 & 0.79 & 1.02 & 0.85 \\
\hline \hline
\end{tabular}

Source: Author's calculations.

IRPF (Impuesto sobre la Renta de las Personas Fínsicas): Personal Income Tax. ISOC (Impuesto de Sociedades): Corporation tax. CSTFE1: Social Contributions under Hypothesis 1. IGTE (Impuesto General sobre el Tráfico de Empresas): General Sales tax. LUJO: Luxury tax. IIEE (Impuestos Especiales): excises on alcohol, petroleum products, and so on. CEXT: Tariffs and other taxes on international trade.

Table 4: Average ETR by deciles, year 1990

\begin{tabular}{lrrrrrrr} 
& IRPF & ISOC & IEPPF & CSTFE1 & IVA & IIEE & COMEXT \\
\hline Decile 1 & 12.43 & 18.35 & 0.00 & 2.74 & 82.33 & 64.81 & 11.66 \\
Decile 2 & 7.53 & 5.51 & 0.00 & 11.78 & 19.99 & 8.43 & 2.62 \\
Decile 3 & 6.33 & 4.33 & 0.00 & 14.53 & 12.18 & 5.37 & 1.55 \\
Decile 4 & 6.86 & 4.07 & 0.00 & 17.14 & 10.32 & 4.37 & 1.31 \\
Decile 5 & 7.58 & 4.05 & 0.01 & 17.22 & 9.39 & 3.76 & 1.18 \\
Decile 6 & 8.12 & 3.85 & 0.01 & 17.20 & 8.15 & 3.26 & 1.01 \\
Decile 7 & 8.78 & 4.03 & 0.03 & 17.20 & 7.97 & 2.91 & 0.96 \\
Decile 8 & 9.93 & 3.85 & 0.05 & 16.90 & 7.43 & 2.95 & 0.88 \\
Decile 9 & 10.71 & 4.05 & 0.12 & 16.23 & 6.68 & 2.02 & 0.77 \\
Decile 10 & 14.02 & 4.54 & 0.40 & 14.61 & 5.96 & 1.61 & 0.66 \\
\hline \hline Top 5\% & 15.30 & 4.78 & 0.58 & 13.65 & 5.20 & 1.15 & 0.57 \\
Top 1\% & 20.65 & 6.89 & 1.49 & 7.38 & 3.53 & 0.76 & 0.39 \\
\hline \hline
\end{tabular}

Source: Author's calculations.

IRPF (Impuesto sobre la Renta de las Personas Físicas): Personal Income Tax. ISOC (Impuesto de Sociedades): Corporation tax. IEPPF: Wealth Tax. CSTFE1: Social Contributions under Hypothesis 1. IVA (Impuesto sobre el Valor Añadido): Value Added Tax. IIEE (Impuestos Especiales): excises on alcohol, petroleum products, and so on. CEXT: Tariffs and other taxes on international trade. 


\section{E Analysis of the 1960s}

We have insufficient information to include these years in the main estimation, but some conclusions about the trends during the decade are allowed. Regressivity probably increased, due to two concurrent changes. On the one hand, a growth of indirect relative to direct taxation: the balance between both went from $68.9 \%$ to $53.3 \%$ in $1960-70$ (likely related to a loss of efficiency in direct taxation, because of evasion and defective tax base estimation procedures). Another composition effect arose from the major increase in social contributions. Because these taxes were borne by labour, they had an undoubtedly negative impact on the distribution of net incomes (notwithstanding their being the basis to finance more generous pensions in the decades to come). A comparison with the work by Perona (1972) for 1965 allows getting a little closer. In figure 1 I plot tax rates by income ranges for 1965 and 1970; the latter have been obtained replicating Perona's methodology, so they are not directly comparable to my main results. Here, I have left aside non-central taxes, used "wide" pre-tax income as denominator (includes all public and private transfers), established the household as the weighting unit, and grouped them according to disposable income. ${ }^{40}$

Figure 1: Average Effective Tax Rates over the 1960s
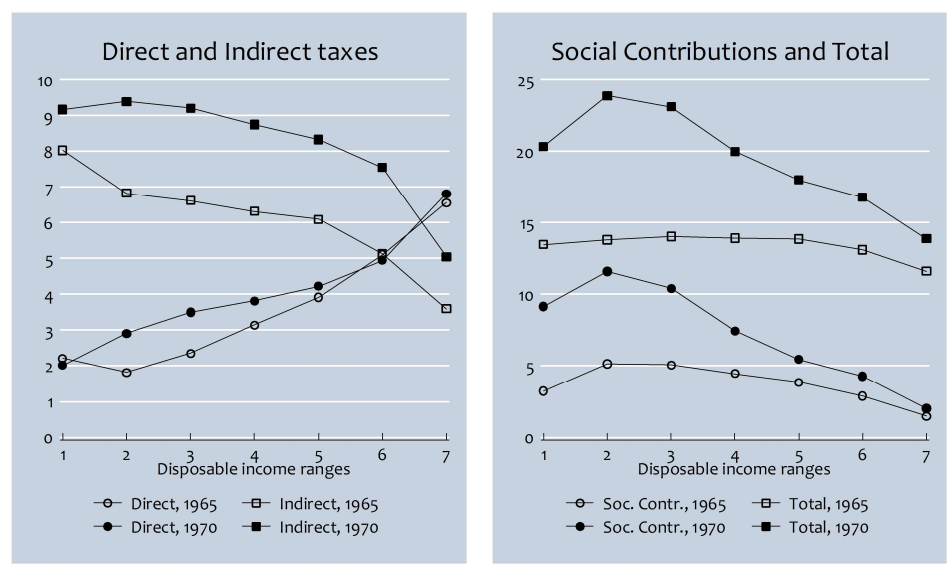

Source: for 1965, Perona (1972); for 1970, author's calculations.

Households are ranked by disposable income, but the denominator for the tax rates is wide income (pre-tax plus all transfers).

We can see lack of significant change in direct taxes (neither in their profile nor in the average level), while indirect tax rates grew over all ranges. Social contributions also experienced a very significant increase, specially affecting the lower income classes. As a joint result, regressivity in terms of total tax rates had been strongly exacerbated. ${ }^{41}$

${ }^{40}$ I have replicated the ranges in Perona's work by keeping the same percentage of households in each group. Approximately, range 1 corresponds to the first decile, range 2 to deciles 2 and 3, range 3 to deciles 4 to 7 , range 4 to deciles 8 and 9 , and the three upper ranges to the top decile.

${ }^{41}$ Recall that rates are calculated here over "wide" income: over pre-tax incomes the systems will look more regressive, since transfers represent a bigger percentage of income for the lower ranges. 


\section{F Alternative (robustness) estimations}

\section{F.1 Consumption taxes}

There is some better data for indirect taxation in the year 1980, disaggregated by INE for a study undertaken in the IEF in the course of preparations for the introduction of VAT. I have used these data to perform two alternative estimations that show no significant deviation from the baseline ones, thus reinforcing the general procedure.

- Domestic consumption taxation: Calatrava and Martínez-Aguado (1985) calculated rates by sector using the input-output table (in this way estimating the cumulative effect of IGTE), and those were used by Argimón et al. (1987) to obtain rates by consumption groups and calculate indirect tax incidence on the Household Budget Survey. They cover IGTE, ICGI, Luxury Tax, Excises, Fiscal Monopolies and Fiscal Licence. I have used their tax rates and compared the resulting AETR over Disposable income by deciles with those from my baseline estimation. The results show the same trend, meaning that the impact of the different estimation procedure is not significant. AETRs are not very different from those given in Argimón et al. (1987), but mine display higher regressivity in the lower deciles: this is attributable to different procedures of correction of the Disposable income given by the HBSs (that study used provintial-level data).

- Tariffs: INE also provided disaggregated tariffs revenue by sectors in 1980 (the only year for which I have been able to find this information). This allows to impute to the corresponding expenditures the taxes falling on final consumption, while maintaining other revenues on total monetary outlays (the disaggregated quantities are $47 \%$ of the total). The results are reassuring: AETRs by deciles change for the most in 0.09 percentage points. It can be concluded that using import taxes as a whole does not introduce a serious problem.

\section{F.2 Incidence of social contributions}

As is discussed in the methodological section, I have estimated an alternative scenario under different assumptions on the incidence of Social contributions, because of the lack of consensus about their impact in the Spanish economy. Hypothesis 2 imputes 50\% of the contributions to labour, $25 \%$ to businesses (income from individual ownership and capital) and $25 \%$ to consumption. This estimation may reflect a situation where workers have gained enough bargaining power to resist the full backwards shifting of this tax onto them, and could be more plausible for the post-transition period (and consistent with a negative effect of social contributions on the levels of employment).

The results are different from the baseline estimates shown in the text, because these contributions made up a very significant part of total tax revenue. With a portion of them falling on capital, they seem a lot less regressive, and this drives the total to a considerable extent: the levels of progressivity and redistribution obtained under hypothesis 2 are higher (less negative) than under the baseline estimation.

In 1982, Social contributions were the most important tax in the system, representing $46 \%$ of that year's revenue (and 12\% of GDP); therefore, with this alternative hypothesis the system appears a lot less regressive in the beginning of the eighties than at the end, displaying a more intense cycle. However, the same general conclusion about the negative impact of taxes on inequality is still valid. 
Table 5: Progressivity and Redistribution under Hypothesis 2

\begin{tabular}{|c|c|c|c|c|}
\hline \multicolumn{5}{|c|}{1970} \\
\hline & Direct & Soc. Contr. & Indirect & Total \\
\hline K & 0.0910 & -0.0307 & -0.1358 & -0.0499 \\
\hline AETR & 4.78 & 8.84 & 9.74 & 23.36 \\
\hline$\underline{\mathrm{RS}}$ & 0.0044 & -0.0041 & -0.0172 & -0.0216 \\
\hline \multicolumn{5}{|c|}{1982} \\
\hline & Direct & Soc. Contr. & Indirect & Total \\
\hline K & 0.1111 & -0.0060 & -0.1794 & -0.0138 \\
\hline AETR & 10.27 & 16.75 & 8.54 & 35.56 \\
\hline RS & 0.0125 & -0.0042 & -0.0182 & -0.0162 \\
\hline \multicolumn{5}{|c|}{1990} \\
\hline & Direct & Soc. Contr. & Indirect & Total \\
\hline K & 0.0854 & -0.0267 & -0.2332 & -0.0439 \\
\hline AETR & 17.56 & 17.22 & 13.56 & 48.34 \\
\hline RS & 0.0164 & -0.0075 & -0.0413 & -0.0632 \\
\hline
\end{tabular}

Source: Author's calculations.

\section{F.3 Incidence of the corporation tax}

Three alternative estimations have been calculated concerning this tax, due to the uncertainty about its economic incidence:

- Alt. A: $100 \%$ on capital. This is an extreme possibility, done for comparability with works that consider it (fundamentally earlier ones). Nunns (2012) reports that the Tax Policy Center in USA recently changed from $100 \%$ to $80 \%$ on capital.

- Alt. 2: $70 \%$ on capital, $30 \%$ on consumption; following the approach taken by Uriel (2003) for Spain.

- Alt. 3: $30 \%$ on capital, $70 \%$ on labor; according to several recent empirical work with data from US and Europe (Dwenger et al., 2011; Arulampalam et al., 2012; Liu and Altshuler, 2013; Fuest et al., 2013) and which fits the developments in theory (e.g. Randolph, 2006).

In all cases, the incidence considered for the Corporation tax is also applied to the part paid by corporations of other taxes (Fiscal Licence, Equity Issuance tax, Tax on the Income from Capital, and so on). As can be seen in table 6, all alternative hypotheses are more progressive than the baseline, entailing a reduction in the \$RS\$RS index of 1-2 Gini points for the most in absolute terms. Thus, the general conclusion of the analysis holds: the tax system got less regressive, and also more negatively redistributive.

Table 6: Alternative incidence of the Corporation tax

\begin{tabular}{|c|c|c|c|c|}
\hline & \multicolumn{4}{|c|}{1970} \\
\hline & Alt. 1 & Alt. 2 & Alt. 3 & Baseline \\
\hline $\mathrm{K}$ & -0.0622 & -0.0771 & -0.0856 & -0.0892 \\
\hline \multirow[t]{2}{*}{$\mathrm{RS}$} & -0.0256 & -0.0305 & -0.0329 & -0.0344 \\
\hline & \multicolumn{4}{|c|}{1982} \\
\hline & Alt. 1 & Alt. 2 & Alt. 3 & Baseline \\
\hline K & -0.0133 & -0.0234 & -0.0262 & -0.0304 \\
\hline \multirow[t]{2}{*}{$\mathrm{RS}$} & -0.0156 & -0.0216 & -0.0229 & -0.0258 \\
\hline & \multicolumn{4}{|c|}{1990} \\
\hline & Alt. 1 & Alt. 2 & Alt. 3 & Baseline \\
\hline $\mathrm{K}$ & -0.0307 & -0.045 & -0.0437 & -0.052 \\
\hline $\mathrm{RS}$ & -0.0461 & -0.0622 & -0.0581 & -0.0694 \\
\hline
\end{tabular}

Source: Author's calculations. 


\section{F.4 Other alternative estimations}

Alternative calculations have been performed for the Real Estate tax (with the hypothesis of 50\% sharing of the burden between the owner and the occupier) and considering different percentages of assumption by households of the local taxes on land plots. The results are not shown here, since they change the indices very marginally. This is not surprising, given the small share of these taxes in total revenue (Real Estate Taxes: 1.1\%, 1.1\%, 1.7\% in 1970, 1982 and 1990 respectively; local land plot taxes: $0.9 \%, 0.7 \%, 0.5 \%)^{42}$

\section{F.5 Public benefits as part of pre-tax income}

Some studies make the methodological choice of using as income reference (denominator in the calculations of AETR and ordering variable for Gini indices) a "wide" gross income which includes public benefits. This is not done in other works, such as Piketty and Saez (2007), while the criterion followed in Bengtsson et al. (2012) is to add only those which are subject to direct taxation. ${ }^{43}$ I have also estimated all the indicators with this alternative framework, in order to compare both.

There are conceptual differences between both calculations. Using Pre-tax income as I have defined it in the main text has the drawback of picturing the lower end of the distribution as extremely poor (with many households having very scarce or no market income at all, and thus above $100 \%$ or even infinite tax rates). Many of these families are led by old-age pensioners. Arguably, if the public benefit system did not exist, their income would be higher than 0 (they might have saved for a private pension); and furthermore a part of what they receive as a benefit is not a pure "transfer" but delayed salary income. In this sense, depicting them as households with null income is an extreme of two options. But it is the choice consistent with:

- Being able to abstract the incidence of taxation from that of public expenditure.

- Considering Social contributions as a tax and introducing them in our analysis as such.

- Judging that public benefits are to a great extent a redistributive transfer; i.e., that recipient households would have significantly lower income if not benefiting from them (as found by Bandrés and Cuenca (1996) for pensions in Spain).

On the contrary, including public benefits in pre-tax income entails not being able to correctly separate the analysis of public expenditure, because it is already included in our reference income. It also means depicting society as less unequal than it is (public benefits being redistributive). The "true" pre-tax distribution probably lies somewhere in the middle of both scenarios.

As was said in the text, HBSs data do not allow to separate public benefits from private transfers for the first two years analysed. ${ }^{44}$ Even though for 1990 it would be possible to do it, to keep consistency in table 7 I have defined Pre-tax income as Gross Factor Income + all Transfers. I call these results Scenario B, while the baseline framework is Scenario A.

Resulting from this methodological change, inequality in pre-tax incomes is lower (33.76 in 1970, 33.53 in 1982 and 34.78 in 1990 ${ }^{45}$. The tax system appears less regressive, making the Gini index increase 2.4 points the first year, then only around 1 , then again 2.5 . The difference with the Scenario A specification grows over time, as a logical consequence of public benefits developing during the period.

Hypothesis 2 regarding Social contributions makes a higher part of the burden fall on top deciles (via partial incidence on capital and employers' incomes; see section

F.2). Therefore, under the alternative estimation, the tax system looks close to proportional in 1982 and 1990. However, the profile of effective tax rates by percentiles under both hypotheses

42 The prevalence of owner-occupied housing in Spain also contributes to the quantitative irrelevance of the alternative estimation in the case of the Real Estate Tax.

${ }^{43}$ In the case of Spain, and following the definition of the Personal Income Tax base, this would mean including retirement and sickness pensions, but not unemployment or disability benefits. However, unemployment benefits are liable to Social Security contributions.

${ }^{44}$ As was said before, $89.5 \%$ of total transfers received by households in 1990 were public, a percentage that might have been lower in preceding years.

${ }^{45}$ Equivalent Pre-tax incomes, weighting by household size. 
still shows significant downward-sloping stretches in the lower classes (first 10-20\% of households). The $\$ R S \$ R S$ index fails to indicate any significantly positive impact of taxes on the distribution of income.

Table 7: Progressivity and redistribution under scenario B

Social Contributions Hypothesis 1 Social Contributions Hypothesis 2

\begin{tabular}{|c|c|c|c|c|c|c|c|c|}
\hline & \multicolumn{8}{|c|}{1970} \\
\hline & Direct & Soc. Contr. & Indirect & Total & Direct & Soc. Contr. & Indirect & Total \\
\hline $\mathrm{K}$ & 0.1114 & -0.1386 & -0.0865 & -0.0661 & 0.1036 & -0.0068 & -0.0950 & -0.0213 \\
\hline AETR & 4.20 & 7.82 & 8.56 & 20.58 & 4.20 & 7.78 & 8.57 & 20.55 \\
\hline \multirow[t]{3}{*}{$\mathrm{RS}$} & 0.0047 & -0.0142 & -0.0104 & -0.0243 & 0.0044 & -0.0016 & -0.0112 & -0.0116 \\
\hline & \multicolumn{8}{|c|}{1982} \\
\hline & Direct & Soc. Contr. & Indirect & Total & Direct & Soc. Contr. & Indirect & Total \\
\hline K & 0.1381 & -0.0153 & -0.1019 & 0.0081 & 0.1272 & 0.0494 & -0.1097 & 0.0337 \\
\hline AETR & 8.37 & 13.75 & 6.96 & 29.08 & 8.38 & 13.67 & 6.97 & 29.02 \\
\hline \multirow[t]{3}{*}{$\mathrm{RS}$} & 0.0119 & -0.0078 & -0.0089 & -0.0096 & 0.0110 & 0.0050 & -0.0094 & 0.0032 \\
\hline & \multicolumn{8}{|c|}{1990} \\
\hline & Direct & Soc. Contr. & Indirect & Total & Direct & Soc. Contr. & Indirect & Total \\
\hline K & 0.1519 & -0.0319 & -0.1589 & -0.0009 & 0.1443 & 0.013 & -0.1649 & 0.0108 \\
\hline AETR & 14.29 & 14.16 & 11.03 & 39.48 & 14.31 & 14.03 & 11.05 & 39.39 \\
\hline $\mathrm{RS}$ & 0.0237 & -0.0102 & -0.0239 & -0.0248 & 0.0226 & -0.0001 & -0.0247 & -0.0147 \\
\hline
\end{tabular}

Source: Author's calculations.

Pre-tax incomes defined as gross market income + all transfers received.

\section{G Data sources for the international comparison}

\section{G.1 Direct tax rates}

- US, UK and France: Piketty and Saez (2007).

- Sweden: Bengtsson et al. (2012)

\section{G.2 Direct taxes and transfers}

- EU-15 countries: Immervoll et al. (2007).

- Other-OECD countries: Wang and Caminada (2011).

\section{G.3 Tax-benefit systems}

- Argentina (2006): Cornia et al. (2011).

- Brazil (2009): Lustig (2011).

- Chile (2003): Jorratt (2010).

- Colombia (2003): Barreix et al. (2006).

- Mexico (2000): Goñi et al. (2011).

- Uruguay (2005): Roca (2010).

- US (1982-2009): Congressional Budget Office (2012). 
- UK (1977-2009): Barnard et al. (2011).

\section{References for the Appendices}

Argimón, I. and J. M. González-Páramo (1987). Traslación e incidencia de las cotizaciones sociales por niveles de renta en España, 1980-1984. Documentos de Trabajo 1/1987, FIES.

Argimón, I., J. M. González-Páramo, and R. Salas (1987). ¿Quién pagaba los impuestos indirectos en España? Un ejercicio de reparto de la carga impositiva indirecta en 1980. Hacienda Pública Española 104, 99-127.

Arulampalam, W., M. P. Devereux, and G. Maffini (2012). The direct incidence of Corporate Income Tax on wages. European Economic Review 56(6), 1038-1054.

Bandrés, E. and A. Cuenca (1996). Análisis y evaluación del contenido redistributivo de las pensiones públicas en España. In II Simposio sobre Igualdad y Distribución de la Renta y la Riqueza, Volume VII. Madrid: Fundación Argentaria.

Barnard, A., S. Howell, and R. Smith (2011). The effects of taxes and benefits on household income, 2009/10. Further analysis and methodology, Office for National Statistics, UK.

Barreix, A., J. Roca, and L. Villela (Eds.) (2006). La equidad fiscal en los países andinos. Washington: BID-Eurosocial.

Bengtsson, N., B. Holmlund, and D. Waldenström (2012). Lifetime versus Annual Tax Progressivity: Sweden, 1968-2009. Working Paper Series 2012:13, Center for Labor Studies, Uppsala University.

Blundell, R. and T. Macurdy (1999). Labor supply: A review of alternative approaches. In O. Ashenfelter and D. Card (Eds.), Handbook of Labor Economics, Volume 3, Chapter 27, pp. 1559-1695. Elsevier.

Bosch-Domenech, A. (1991). Economies of scale, location, age, and sex discrimination in household demand. European Economic Review 35, 1589-1595.

Cabrera, M. and F. Del Rey (2002). El poder de los empresarios. Política y economía en la España contemporánea: 1875-2000. Madrid: Taurus.

Calatrava, A. and Martínez-Aguado (1985). Determinación de la cuota visible y en cascada soportada por los sectores de las TIOE-80 y proyección a 1985. Technical report, Instituto de Estudios Fiscales.

Congressional Budget Office (2012). The Distribution of Household Income and Federal Taxes, 2008 and 2009. Technical Report 4441. Supplementary Tables.

Cornia, G., J. Gómez-Sabaini, and B. Martorano (2011). A New Fiscal Pact, Tax Policy Changes and Income Inequality. Latin America during the last decade. Working Paper 2011/70, United Nations University, World Institute for Development Economic Research.

Cronin, J. (1999). US Treasury Distributional Analysis Methodology. Paper 85, Office for Tax Analysis, US Department of the Treasury.

Davies, J., F. S. Hilaire, and J. Whalley (1984). Some calculations of lifetime tax incidence. American Economic Review 74, 633-649.

Duclos, J.-Y. and M. Mercader-Prats (1999). Household Needs and Poverty: With Application to Spain and the U.K. Review of Income and Wealth 45(1), 77-98.

Dwenger, N., P. Rattenhuber, and V. Steiner (2011). Sharing the burden: Empirical evidence on corporate tax incidence. Discussion Papers 2011/19, Free University Berlin, School of Business \& Economics.

Escobedo, M. I. (1991). Un análisis empírico de los efectos finales producidos sobre el empleo industrial por el sistema de financiación de la Seguridad Social española, 1975-1983. Investigaciones Económicas XV(1), 169-192.

Fernández Val, I. (2003). Household labor supply: evidence for Spain. Investigaciones Económicas 27(2), 239-275.

Fuest, C., A. Peichl, and S. Siegloch (2013). Do Higher Corporate Taxes Reduce Wages? Micro Evidence from Germany. CESifo Working Paper Series 4247, CESifo Group Munich.

Fullerton, D. and D. Rogers (1993). Who Bears the Lifetime Tax Burden? Washington DC: Brookings Institution. 
Goñi, E., H. López, and L. Servén (2011). Fiscal Redistribution and Income Inequality in Latin America. World Development 39(9), 1558-1569.

Gruber, J. (1997). The Incidence of Payroll Taxation: Evidence from Chile. Journal of Labor Economics 15(3), 72-101.

Gruber, J. and A. B. Krueger (1991). The Incidence of Mandated Employer-Provided Insurance: Lessons from Workers' Compensation Insurance. In Tax Policy and the Economy, Volume 5, NBER Chapters, pp. 111-144.

Immervoll, H., H. Levy, C. Lietz, D. Mantovani, C. O’Donoghue, H. Sutherland, and G. Verbist (2007). Household Incomes and Redistribution in the European Union: Quantifying the Equalising Properties of Taxes and Benefits. Working Paper 48, European Network of Economic Policy Research Institutes.

Instituto de Estudios Fiscales (2014). Base de Datos Económicos del Sector Público Español. http://www.estadief.meh.es/.

Instituto Nacional de Estadística (1968). Contabilidad Nacional de España, años 1965, 1966 y avance de 1967. Madrid: INE.

Instituto Nacional de Estadística (1992). Encuesta de Presupuestos Familiares 1990-91. Metodología. Madrid: INE.

Jorratt, M. (2010). Equidad Fiscal en Chile: Un Análisis de la Incidencia Distributiva de los Impuestos y el Gasto Social. In Equidad Fiscal en Brasil, Chile, Paraguay y Uruguay. BID - Eurosocial.

Labeaga, J., I. Preston, and J. Sanchis-Llopis (2004). Demanda y escalas de equivalencia: evidencia para España. Cuadernos Económicos del ICE 68, 63-87.

Lagares, M. J. (1976). Traslación e incidencia de la imposición sobre beneficios. Investigaciones Económicas 1, 9-43.

Liu, L. and R. Altshuler (2013). Measuring The Burden Of The Corporate Income Tax Under Imperfect Competition. National Tax Journal 66(1), 215-37.

Lustig, N. (2011). Fiscal policy and income redistribution in Latin America: challenging the conventional wisdom. Working Paper 227, ECINEQ, Society for the Study of Economic Inequality.

Melguizo, A. (2007). La incidencia económica de las cotizaciones sociales en España. Working Paper 0702, International Economics Institute, University of Valencia.

Mieszkowski, P. (1972). The property tax: An excise tax or a profits tax? Journal of Public Economics 1(1), 73-96.

Molinero, C. and P. Ysàs (1998). Productores disciplinados y minorías subversivas: clase obrera y conflictividad laboral en la España franquista. Madrid: Siglo XXI de España.

Nunns, J. (2012). How TPC distributes the Corporate Income Tax. Technical report, Tax Policy Center.

Perona, D. (1972). La distribución de la carga tributaria en España. Madrid: Instituto de Estudios Fiscales.

Piketty, T. and E. Saez (2007). How Progressive Is the U.S. Federal Tax System? A Historical and International Perspective. Journal of Economic Perspectives 21(1), 3-24.

Poterba, J. (1989). Lifetime Incidence and the Distributional Burden of Excise Taxes. American Economic Review 79, 325-330.

Randolph, W. (2006). International Burdens of the Corporate Income Tax. Working Paper Series 2006-09, Congressional Budget Office.

Roca, J. (2010). Equidad Fiscal en Uruguay. Cuánto y cómo modifica el Estado el bienestar de los uruguayos. In Equidad Fiscal en Brasil, Chile, Paraguay y Uruguay. BID - Eurosocial.

Toharia, L. (1981). Precios, costes, beneficios y la "tasa justificada de inflación" en la economía española (1965-79). Investigaciones Económicas 16, 125-150.

Uriel, E. (2003). Una aproximación a las balanzas fiscales de las Comunidades Autónomas. Bilbao: Fundación BBVA.

Wang, C. and K. Caminada (2011). Disentangling Income Inequality and the Redistributive Effect of Social Transfers and Taxes in 36 LIS Countries. MPRA Paper 32821. 